\title{
Discovery of Heterodera filipjevi in Washington and Comparative Virulence with $H$. avenae on Wheat
}

Richard W. Smiley and Guiping Yan, Oregon State University, Columbia Basin Agricultural Research Center, P.O. Box 370, Pendleton, OR 97801

\begin{abstract}
Smiley, R. W., and Yan, G. P. 2015. Discovery of Heterodera filipjevi in Washington and comparative virulence with H. avenae on wheat. Plant Dis. 99:376-386.

The cereal cyst nematode Heterodera avenae suppresses wheat production in the western United States. A second species of cereal cyst nematode, $H$. filipjevi, was identified in eastern Oregon during 2008. This paper reports the discovery of $H$. filipjevi-infested fields in eastern Washington, thereby extending the known distribution of $H$. filipjevi in the United States. The identity of $H$. filipjevi was determined and confirmed by species-specific polymerase chain reaction (PCR), PCRrestriction fragment length polymorphism (RFLP), sequencing, and cyst morphology. Soils that were collected from naturally infested fields in Washington were used to compare the virulence of $H$. avenae and $H$. filipjevi on six spring wheat cultivars under controlled-environ-

ment conditions. Noninfested soils from nearby fields were used as controls. Cultivars Ouyen and WB Rockland were resistant to $H$. avenae and susceptible to $H$. filipjevi. Cultivars Sönmez and SY Steelhead were resistant to $H$. filipjevi and susceptible to $H$. avenae. Cultivars Louise and WB 936 were susceptible to both species. The resistance of SY Steelhead to ' $H$. avenae', reported in a previous paper, is corrected as resistance to $H$. filipjevi due to an earlier misidentification of $H$. filipjevi. Management guidelines that include crop rotations and resistant cultivars are presented. Discovery of additional infestations of $H$. filipjevi are anticipated when DNA-based tests become used routinely in commercial diagnostic laboratories.
\end{abstract}

Cereal cyst nematodes $(\mathrm{CCN})$ are a widespread and important group of sedentary plant-parasitic nematodes that restrict production of cereal crops throughout the world $(5,28,35,49,60)$. Twelve species in the Heterodera avenae complex (14) invade roots of cereals and grasses, of which $H$. avenae Wollenweber, 1924, $H$. filipjevi (Madzhidov, 1981) Stone, 1985, and H. latipons Franklin, 1969 are the most economically important to cultivated cereals worldwide $(28,35,49)$.

H. avenae was first detected in the United States in 1974, in western Oregon (20), and is now reported in seven western states that include the Pacific Northwest (PNW) states of Idaho, Oregon, and Washington (43). H. avenae has reduced yields of susceptible wheat cultivars by as much as $64 \%(43,46,48,50)$ and is estimated to reduce the profitability of wheat production by at least $\$ 3.4$ million annually in the PNW (43).

H. filipjevi was first detected in the United States in 2008 $(51,64)$. Both $H$. avenae and $H$. filipjevi occur in Oregon (65), but the extent to which $H$. filipjevi occurs elsewhere in the western United States remains unclear. $H$. filipjevi is closely related to $H$. avenae in the $H$. avenae group complex, and morphological differences on cysts and second-stage juveniles are very minor (14,17,53). Distinction between $H$. avenae and $H$. filipjevi using microscopic procedures is time-consuming and requires skill, training, and good-quality nematode specimens (65). Commercial laboratories in the PNW therefore routinely identify $\mathrm{CCN}$ only to the genus level. They report "cereal Heterodera spp." as differentiated from "beet Heterodera spp." but do not differentiate $H$. avenae from $H$. filipjevi.

Corresponding author: Richard Smiley,

E-mail: richard.smiley@oregonstate.edu

Current address of Guiping Yan: North Dakota State University, Department of Plant Pathology, P.O. Box 6050, Fargo, ND 58108.

Accepted for publication 24 September 2014.

http://dx.doi.org/10.1094/PDIS-08-14-0789-RE

(c) 2015 The American Phytopathological Society
Distinguishing between $H$. avenae and $H$. filipjevi is important because current control practices are limited. Both species can be controlled using rotations in which susceptible cereals are not produced more than once in a 3-year interval $(28,35,49,60)$. However, long rotations including broad-leaf crops and long periods of fallow are of limited value to producers in PNW wheat-producing regions where other crops are less profitable than wheat. Wheat is therefore produced mostly in 2-year rotations that do not adequately suppress the nematode density before the next crop of susceptible wheat is planted. Spring wheat cultivars with resistance to $H$. avenae were recently identified $(47,48)$, but resistance to $H$. filipjevi has not been evaluated in the PNW. Research in other countries indicated that individual wheat cultivars may differ in their ability to serve as hosts of these two nematodes; cultivars resistant to $H$. avenae may not be resistant to $H$. filipjevi, and vice versa (29).

Molecular techniques offer more rapid and accurate alternatives for distinguishing species of cereal cyst nematodes than can be achieved with morphological identification. Polymerase chain reaction-restriction fragment length polymorphisms (PCR-RFLP) based on the internal transcribed spacer (ITS) region of the ribosomal DNA repeat unit has facilitated quick and precise identification of plant-parasitic nematode species including cyst nematode species and subspecies $(1,6,26,36,54,55)$. Yan and Smiley (65) optimized a PCR-RFLP procedure to discriminate the species of Heterodera populations collected from infested fields in Oregon. Since the protocol was based on cleavage by up to six restriction endonucleases, and was expensive, a single-step PCR was preferred. To overcome that limitation, Yan et al. (67) developed a robust and species-specific PCR assay to differentiate $H$. filipjevi from $H$. avenae, and concluded that assays for both species would enhance the diagnosis of CCN species in PNW wheat fields.

In April 2014, the authors of this paper received a fresh sample of $H$. avenae from a field in Washington that had not been included in our earlier laboratory, greenhouse, and field studies with populations of $H$. avenae $(48,52,65,67)$. The sample consisted of soil containing dislodged brown cysts and wheat stubble in which white females remained embedded in roots. Initial PCR evaluations of DNA from eggs taken from brown cysts extracted from the soil and from swollen white females attached to roots indicated that the 
population from the new sample was not $H$. avenae. The PCR method used (67) has been consistently efficient in detecting $H$. avenae but not detecting other species of $\mathrm{CCN}$ in $\mathrm{PNW}$ wheat field soils.

The objectives of this study were to identify the species of CCN in the sample from Washington, to determine whether other fields near the collection site were also infested with that species, and to compare the virulence of that species with populations of $H$. avenae from nearby fields in the same region.

\section{Materials and Methods}

Identification. White females were extracted by picking them directly from root tissue and transferring them to an Eppendorf tube containing sterile water. Brown cysts were also extracted from soil using the sieving-decanting method (19) in which soil was placed on the top of a set of sieves consisting of 710-, 425-, and $250-\mu \mathrm{m}$-pore sieves. Cysts collected on the bottom sieve $(250 \mu \mathrm{m})$ were picked with a dissecting needle under a stereomicroscope, transferred to an Eppendorf tube containing sterile water, and stored at $4{ }^{\circ} \mathrm{C}$ for nematode identification. Motile juveniles were isolated from soil samples using the Whitehead tray method (62). For soil samples with high population densities, approximately 50 eggs from at least five cysts or 50 second-stage juveniles from each soil sample were placed in $40 \mu \mathrm{l}$ of sterile PCR-grade water on a concave glass slide and cut into pieces under a microscope. For soil samples with low population densities, approximately 20 eggs or second-stage juveniles from each soil sample were used and placed in $20 \mu \mathrm{l}$ of sterile water. DNA was extracted from these nematodes using previously described methods $(65,67)$. Briefly, the nematode suspension was transferred to a $0.5-\mathrm{ml}$ sterile tube containing worm lysis buffer $(500 \mathrm{mM} \mathrm{KCl}, 100 \mathrm{mM}$ Tris- $\mathrm{HCl} \mathrm{PH}$ $8.3,15 \mathrm{mM} \mathrm{MgCl}, 10 \mathrm{mM}$ DTT, $4.5 \%$ Tween $20,0.1 \%$ gelatin). The contents were immediately frozen at $-20^{\circ} \mathrm{C}$ for at least $20 \mathrm{~min}$. The nematode suspension was thawed and proteinase $\mathrm{K}$ was added into each sample. The tubes were incubated at $65^{\circ} \mathrm{C}$ for $1 \mathrm{~h}$ and then at $95^{\circ} \mathrm{C}$ for $10 \mathrm{~min}$ to inactivate the proteinase $\mathrm{K}$. The nematode lysis mix was centrifuged and the supernatant was transferred to a clean $0.5 \mathrm{ml}$ tube and frozen at $-20^{\circ} \mathrm{C}$ until used for the following PCR assays. DNA was quantified using a NanoDrop 2000c Spectrophotometer (Wilmington, DE).

Species-specific PCR assays (67) were conducted to determine species identity. The primers HaITS-F6 (5'-ATGCCCCCGTCT GCTGA-3') and HaITS-R4 (5'-GAGCGTGCTCGTCCAAC-3'), with an amplicon size of $242 \mathrm{bp}$, were used to identify $H$. avenae. The forward PCR primer HfITS-F1 (5'-CCCGTCTGCTGT TGAGA-3') and reverse primer HfITS-R1 (5'-ACCTCAGGCTTT TATTATCAC-3'), with an amplicon size of $170 \mathrm{bp}$, were used to identify $H$. filipjevi. PCR reactions in a volume of $25 \mu \mathrm{l}$ consisted of the DNA template $(3 \mu \mathrm{l}), 1 \times$ PCR buffer, $0.2 \mathrm{mM}$ dNTPs, $1 \times$ Cresol Red in $20 \%$ glycerol, $0.5 \mu \mathrm{M}$ each of forward and reverse primers, and 0.75 units of $T a q$ polymerase (Roche, Mannheim, Germany). PCR amplification was carried out in a MyCycler Thermal Cycler (Bio-Rad, Richmond, CA). The amplification program was as follows: one initial cycle of denaturation at $95^{\circ} \mathrm{C}$ for $3 \mathrm{~min}, 35$ cycles of $95^{\circ} \mathrm{C}$ for $30 \mathrm{~s}, 58^{\circ} \mathrm{C}$ (Hf ITS-F1/Hf ITS-R1) or $64^{\circ} \mathrm{C}$ (HaITS-F6/HaITS-R4) for $30 \mathrm{~s}$, and $72^{\circ} \mathrm{C}$ for $30 \mathrm{~s}$, and a final extension of $72^{\circ} \mathrm{C}$ for $7 \mathrm{~min}$. PCR products were separated on $2 \%$ agarose using $0.5 \times$ TBE buffer $(45 \mathrm{mM}$ Tris-borate, $2 \mathrm{mM}$ EDTA, pH 8.0), and stained with ethidium bromide. Amplicon sizes were extrapolated using a 100-bp DNA ladder (Roche). Banding patterns were visualized under UV light and photographed using a Polaroid digital camera (Polaroid, Bedford, MA).

PCR-RFLP assays (65) were conducted to confirm the species identity. Primers $18 \mathrm{~S}$ (5'-TTGATTACGTCCCTGCCCTTT-3') and 26S (5'-TTTCACTCGCCGTTACTAAGG-3') were used to amplify the ITS region of rDNA. PCR reactions in a volume of $20 \mu \mathrm{l}$ consisted of the DNA template $(3 \mu \mathrm{l}), 1 \times$ PCR buffer with $1.5 \mathrm{mM}$ $\mathrm{MgCl}_{2}, 0.2 \mathrm{mM}$ dNTPs, $0.5 \mu \mathrm{M}$ each primer, $0.5 \mathrm{mM} \mathrm{MgCl}_{2}$, and 1.25 units of $T a q$ polymerase (Roche). PCR amplification was performed as follows: $94^{\circ} \mathrm{C}$ for $2 \mathrm{~min}$, followed by 40 cycles of $94^{\circ} \mathrm{C}$ for $1 \mathrm{~min}, 60^{\circ} \mathrm{C}$ for $50 \mathrm{~s}$, and $72^{\circ} \mathrm{C}$ for $1 \mathrm{~min}$, with a final extension at $72^{\circ} \mathrm{C}$ for $7 \mathrm{~min}$. Each PCR product $(5 \mu \mathrm{l})$ was mixed with $1 \mu \mathrm{l}$ of $6 \times$ loading buffer (bromophenol blue in sucrose or cresol red in glycerol) and examined in a $1.8 \%$ agarose gel stained with ethidium bromide to check the success of PCR amplification. The remaining product was stored at $-20^{\circ} \mathrm{C}$. Three restriction endonucleases (TaqI, Hinf, and RsaI) (Roche) were used for digestions, which were carried out in $15-\mu$ reaction mixtures containing 2 units of enzyme, $1 \times$ enzyme buffer, and $10 \mu \mathrm{l}$ of PCR product at optimum incubation conditions as recommended by the manufacturer for each enzyme. The DNA fragments were partitioned on $1.8 \%$ agarose using $0.5 \times \mathrm{TBE}$ buffer, and the length of fragments was estimated by a 100-bp DNA ladder (Roche). The species of Heterodera was determined by comparing restriction patterns with those of control species. DNA standards of $H$. latipons and $H$. schachtii were acquired from cooperators in Belgium and France and used as the controls. Isolates of $H$. avenae (St. Anthony, ID) and H. filipjevi (Imbler, OR), verified in previous experiments (67), were also used as controls.

Sequencing was conducted to confirm the species identity. The forward $18 \mathrm{~S}$ and reverse $26 \mathrm{~S}$ primers were used to amplify the ITS region of rDNA (65). PCR reactions and amplification were performed as described above. Each PCR product $(5 \mu \mathrm{l})$ was mixed with $1 \mu$ l of $6 \times$ loading buffer (cresol red in glycerol) and examined in a $1.5 \%$ agarose gel stained with ethidium bromide to check the quality of PCR amplification. The length and concentration of PCR products were estimated by a 100-bp DNA ladder (New England Biolabs Inc., Ipswich, MA). The PCR products were purified and sequenced at Beckman Coulter Genomics (Beckman Coulter, Brea, CA). The primers $18 \mathrm{~S}$ and $26 \mathrm{~S}$ as well as two internal primers 5.8SM2 (5'-CTTATCGGTGGATCACTCGG-3') and 5.8SM5 (5'-GGCGCAATGTGCATTCGA-3') $(31,53)$ were submitted for sequencing. DNA sequences were edited using the program $\mathrm{Bi}$ oEdit ver. 7.0.5.3 (13) and deposited in GenBank with accession numbers KM504378 and KM504379. The sequences were compared with those of known cyst nematode species from GenBank using the BLAST program.

Morphological examinations were performed for selected samples to validate the species identity. Key morphological features of the cysts, including color, underbridge in the vulval cone, semifenestrae shape, and development of bullae, were used to differentiate $H$. filipjevi from $H$. avenae (65). To observe the underbridge and semifenestra, the vulval cone with intact fenestral area was excised from the cyst using a stereomicroscope and observed at $\times 40$ magnification using a Leica compound light microscope (65). For each population, cyst characters were evaluated on four to eight specimens.

Distribution. Nineteen soil samples were collected from commercial fields in southeast Whitman County, WA on 19 April 2014. Soils were not sampled in northeast Whitman County because previous research had shown four populations of Heterodera spp. from that region to be $H$. avenae, including fields near Cashup, Colfax, Palouse, and Steptoe $(48,52,65,67)$. Sampling sites were selected to meet one or more of the following criteria: (i) sites near State Route 26, between the towns of Dusty and Colfax, where $H$. avenae had been previously confirmed (67); (ii) sites near U.S. Route 195, between Colfax and Uniontown, where public- or private-sector wheat or pulse cultivar research trials had been located, as observed using Google Earth version 7.1.2.2.2041 imagery data dated 4 July 2013, 5 July 2013, and 24 July 2013, and including the wheat cultivar screening trial from which the initial sample had been collected (reported previously as Figure 4 in Smiley et al. [48]); or (iii) sites south of Uniontown near the location where an infestation of ' $H$. avenae' was first detected in Washington in 1984 (11). The location of the latter sample was from a field shown on a map that was hand-drawn in 1984 by the collector of that specimen: J. Pinkerton. The presence of a cereal Heterodera spp. at that location was reconfirmed in 2008 (R. Smiley, unreported data).

The 19 soil samples were collected from fields that were (i) planted to winter wheat the previous autumn, (ii) currently being 
planted to spring wheat, or (iii) being planted to a pulse crop such as lentil (Lens culinaris Medik.), field pea (Pisum sativum L.), or chickpea (Cicer arietinum L.). Fields in the region are typically planted to a 2-year rotation of winter wheat and a pulse crop, or a 3 -year rotation of winter wheat, spring wheat, and a pulse crop. No previous knowledge of infestations with cereal Heterodera spp. existed for 17 of the 19 sampling locations, and no patches of stunted or uneven growth were noted in the winter wheat fields that were sampled; spring crops were not yet planted when fields were sampled on 19 April. Soil samples consisted of a composite of 10 shovel slices $2.5-\mathrm{cm}$ thick, $10-\mathrm{cm}$ wide, and $15-\mathrm{cm}$ deep from $2-$ to 4-ha areas of each field. The geographic coordinates of each collection site were recorded using Google Earth's World Geodetic System of 1984 (WGS84) datum imagery that is based on the Simple Cylindrical (Plate Carree) Projection (https://support.google. com/earth/answer/148110?hl=en).

Soil was placed into plastic bags and stored at $4{ }^{\circ} \mathrm{C}$ for 2 days. Subsamples (500 g) were sent to Western Laboratories (Parma, ID) for extraction and microscopic enumeration of all plant-parasitic nematodes. Western Laboratories uses a modified Oostenbrink elutriator extraction method (19). All vermiform and encysted life stages are extracted and collected on separate sieves. Cysts were broken mechanically to extract eggs and larvae and added to the suspension of vermiform life stages. The suspension was then concentrated through multiple sequences of centrifugation and density flotation using an $\mathrm{MgSO}_{4}$ solution. All plant-parasitic nematodes were enumerated at the genus level. The Heterodera counts included eggs and juveniles from crushed cysts as well as juveniles extracted directly from the soil matrix. Western Laboratories returned suspensions from each sample to our laboratory for species identification using molecular and morphological procedures (67). Additional cysts were also extracted from soils retained from the original sample using the sieving-decanting method, and from those soils we extracted juveniles using the Whitehead tray method. These additional extractions provided specimens collected independently for additional species identification in our laboratory.

Nematode DNA was extracted in at least duplicate from each soil sample using the abovementioned worm lysis buffer. Speciesspecific PCR was carried out in duplicate for each extract. For selected samples, the species identity was also confirmed by comparing the PCR-RFLP restriction pattern with those of known species and by examining key morphological features of the cysts under a compound microscope (65).

Based upon identification of Heterodera spp. in soils collected on 19 April, a second field survey was performed on 7 May 2014. Sixteen samples were collected from fields that included the site of the unknown Heterodera spp. near Colton, and 14 additional sites at $0.5-$ to $1-\mathrm{km}$ intervals to distances of $4 \mathrm{~km}$ north and $4 \mathrm{~km}$ south of the site of interest. These samplings were in low-lying areas of fields near the northward-flowing Union Flat Creek. Additionally, one sample was collected north of Pullman, where H. avenae was suspected of being the only Heterodera species present (reported previously as Figure 3 in Smiley et al. [48]). Samples were collected and processed as described previously for quantifications by Western Laboratories and for species identification by our laboratory.

Virulence of Heterodera spp. to spring wheat cv. Louise. Reproduction of Heterodera spp. on spring wheat cv. Louise was examined under controlled-environmental conditions using soils collected from naturally infested fields. Louise is susceptible to PNW populations of $H$. avenae $(45,48)$ and has not been examined for its reaction to H. filipjevi. Soils were collected on 19 April 2014 from three Whitman County fields located within $3 \mathrm{~km}$ of each other. One field was infested with $H$. avenae (Table 1, Soil \#15), one field was infested with $H$. filipjevi (\#12), and neither species was detected in another field (\#11). Each soil was a Covello silt loam, a coarse-silty, mixed, superactive, mesic Cumulic Haploxerolls. This soil series consists of deep, somewhat poorly drained soil formed on nearly level bottom lands along streams. Soil \#12 was collected from the site reported previously as the Colton, WA site in Figure 4 of Smiley et al. (48).

The assay was conducted in large cones measuring 6.4-cm top diameter $\times 25.4-\mathrm{cm}$ tall (D40 Deepots; Stuewe and Sons, Inc., Corvallis, OR). The bottom of each cone was filled with $3 / 4$-minus gravel to a depth covering the drainage holes. The gravel was washed and then $600 \mathrm{~g}$ of soil was placed over the gravel. Soils were collected as described above in the "Distribution" section and stored at $4{ }^{\circ} \mathrm{C}$ until dispensed into the assay pots.

On 30 April, one seed of Louise was planted at $1-\mathrm{cm}$ depth into each of three replicate pots of each of the three soils. Pots were arranged in a randomized complete block design in support trays and incubated in a controlled environment chamber at $15^{\circ} \mathrm{C}$ with a 12-h light interval for 5 weeks and then for a further 3 weeks at $18^{\circ} \mathrm{C}$ with a 15 -h light interval. Light was supplied by four fluorescent F32T8 Super 750 Envir-O-Light lamps (Service Lighting Supply Co., Sewickley, PA) that produced 2,750 lumens at a color temperature of 5,000 Kelvin and a color rendering index of 75. Soil was watered from the top whenever necessary to maintain a continuously moist soil surface. No supplemental fertilizer was provided.

Plant growth was terminated 8 weeks after planting, at which time 357 growing-degree days had accumulated after seedling emergence, using an $8^{\circ} \mathrm{C}$ base for calculating the development of Heterodera species (12). Our harvest date was selected based upon a report that 358 degree days are required for development of fully embryonated eggs following the invasion of roots by $H$. filipjevi (12). This calculation begins when roots become available for invasion, shortly before seedling emergence.

Plant height was measured and then the shoot was severed from the root. Swollen white females and older brown cysts were extracted from roots and soil using a strong spray of water over a nested set of 710- and 250- $\mu \mathrm{m}$-pore sieves. Swollen white females were dislodged from roots by manually rubbing the roots (23). Females and soil debris were washed from the 60-mesh sieve (0.25-mm openings) into a fluidizing column (44) operated at a vertical flow rate of $63 \mathrm{ml} / \mathrm{s}$. White females, brown cysts, and associated organic debris were collected on another 60-mesh sieve and were washed onto 24-cm-diameter qualitative filter papers (grade 631 ) in a gravity-dependent Buchner funnel. Newly produced white females were counted at $\times 0.8$ magnification using a Zeiss dissecting microscope. Shoots and roots were dried at $60^{\circ} \mathrm{C}$ for 2 days and weighed.

The vulval cones of 10 randomly selected newly produced white females from each Heterodera-infested soil were examined to determine presence or absence of an underbridge using the totomount water agar method (9). White females were placed on the surface of a thin layer of water agar in a petri dish and then pushed into the agar with the posterior end facing directly upward to allow examination of the presence or absence of an underbridge. Females having no underbridge were classified as $H$. avenae and females with an underbridge were $H$. filipjevi $(14,65)$.

Before drying, roots were examined visually for incidence and severity of the classical root knotting symptom in which adventitious roots proliferate at points on the root axis where the nematode established a specialized feeding cell (49). Incidence was calculated as the percentage of plants exhibiting at least one knotted root. The severity rating scale was as follows: $1=$ no evidence of damage, $2=1$ to 3 knots $/$ root system, $3=3$ to 5 knots, $4=>5$ knots and $<20 \%$ reduction in plant height or root mass, and $5=>5$ knots and $>20 \%$ reduction in plant height or root mass.

The experiment was repeated on 12 May using soils collected on 7 May. The three silt loams used for the second repetition of this experiment are shown in Table 1 as \#22 (no Heterodera spp.), \#28 (H. filipjevi), and \#36 (H. avenae). Soil \#28 was collected from the site reported previously as the Colton, WA site in Figure 4 of Smiley et al. (48), and Soil \#36 was collected from the site reported previously as the Pullman, WA site in Figure 3 of Smiley et al. (48). All procedures were the same as described for the first experiment except that the entire incubation was performed at $18^{\circ} \mathrm{C}$ and a 
15-h light interval, and the harvest date was at 406 degree days following seedling emergence.

Virulence on six spring wheat cultivars. Six spring wheat cultivars were assayed in Covello silt loam, one of which contained no detectable Heterodera spp. (Table 1, Soil \#11) and two of which were naturally infested with population densities of about 4,500 eggs plus juveniles of either H. avenae (\#3) or H. filipjevi (\#12). Each soil was collected during the field survey performed on 19 April.

The assay was initiated on 30 April using methods similar to those described for virulence assays with cv. Louise, except that plants were assayed in small cones measuring $3.8-\mathrm{cm}$ top diameter $\times 20-\mathrm{cm}$ tall (Ray Leach S10 Super Cone-tainers; Stuewe and Sons, Inc.). Individual cones were filled with $120 \mathrm{~g}$ of soil. Cultivars assayed in this experiment included Louise, 'Ouyen', 'WB 936', 'WB Rockland', 'Sönmez', and 'SY Steelhead'. As with Louise, WB 936 is susceptible to PNW populations of $H$. avenae $(45,47,48)$ and has an unknown reaction to $H$. filipjevi. Ouyen is an Australian cultivar (27) that contains the single dominant Cre 1 gene for resistance to $H$. avenae (41; http://wheatpedigree.net/sort/
renderPedigree/15032) and is resistant to PNW populations of $H$. avenae $(45,52)$. WB Rockland is resistant to PNW populations of H. avenae $(45,47,48)$. Sönmez (CIMMYT Turkey ACC 950193) exhibits moderate resistance to $H$. filipjevi in Turkey (38) and is susceptible to PNW populations of $H$. avenae $(45,48)$. SY Steelhead (tested as SY-97621-05) was resistant to the CCN population in Soils \#12 and \#28 (Table 1) during a field trial in 2012 at the Colton, WA site from which these soils were collected (48).

Phenotypic resistance reactions were assigned using the rating scale of Lücke (25). Mean number of white females produced per plant were compared with the number produced on the preassigned susceptible control cultivar Louise. Resistance reactions were VR $=$ resistant $(\leq 1 \%$ of white females produced on susceptible control), $\mathrm{R}=$ resistant (1.1 to $5 \%), \mathrm{MR}=$ moderately resistant (5.1 to $15 \%), \mathrm{MS}=$ moderately susceptible $(15.1$ to $30 \%), \mathrm{S}=$ susceptible (30.1 to $60 \%)$, VS $=$ very susceptible $(>60 \%)$.

As for the trial with cv. Louise, the presence or absence of an underbridge was examined on 10 randomly selected white females taken from the roots of Louise in each Heterodera-infested soil.

Table 1. Soil sampling sites and Heterodera spp. detected in 36 Whitman County, WA fields samples on two dates during 2014

\begin{tabular}{|c|c|c|c|c|c|c|c|c|c|}
\hline \multirow[b]{2}{*}{ Soil no. } & \multirow[b]{2}{*}{ Sampling date } & \multirow[b]{2}{*}{ Nearest city } & \multicolumn{2}{|c|}{ Coordinates $^{r}$} & \multirow[b]{2}{*}{ Soil series ${ }^{t}$} & \multicolumn{2}{|c|}{ Heterodera spp. } & \multicolumn{2}{|c|}{ Identifieds by: } \\
\hline & & & Latitude & Longitude & & Density $^{u}$ & Species & PCR & RFLP \\
\hline $1^{\mathrm{v}}$ & $19 \mathrm{Apr}$ & Colfax & 46.876940 & -117.434758 & Palouse & 2,280 & avenae & $\mathrm{x}$ & $\mathrm{x}$ \\
\hline 2 & $19 \mathrm{Apr}$ & Colfax & 46.862116 & -117.431471 & Snow & 280 & avenae & $\mathrm{x}$ & $\mathrm{x}$ \\
\hline 3 & $19 \mathrm{Apr}$ & Colfax & 46.854661 & -117.420743 & Covello & 4,520 & avenae & $\mathrm{x}$ & $\mathrm{x}$ \\
\hline 4 & $19 \mathrm{Apr}$ & Colfax & 46.850387 & -117.413162 & Covello & 1,480 & avenae & $\mathrm{x}$ & $\mathrm{x}$ \\
\hline $5^{w}$ & $19 \mathrm{Apr}$ & Colfax & 46.846498 & -117.400403 & Covello & 4,080 & avenae & $\mathrm{x}$ & $\mathrm{x}$ \\
\hline 6 & $19 \mathrm{Apr}$ & Colfax & 46.825155 & -117.326034 & Thatuna/Latah & 760 & avenae + filipjevi & $\mathrm{x}$ & $\mathrm{x}$ \\
\hline $7^{v}$ & $19 \mathrm{Apr}$ & Colfax & 46.807961 & -117.317613 & Palouse & 0 & $\ldots$ & & \\
\hline 8 & 19 Apr & Pullman & 46.768160 & -117.272408 & Latah & 40 & avenae & $\mathrm{x}$ & $\mathrm{x}$ \\
\hline $9^{v}$ & $19 \mathrm{Apr}$ & Pullman & 46.691958 & -117.139290 & Tucannon/Konert & 40 & nd & $\mathrm{nt}$ & nt \\
\hline 10 & 19 Apr & Colton & 46.592109 & -117.176165 & Konert & 0 & $\ldots$ & & \\
\hline $11^{\mathrm{v}}$ & 19 Apr & Colton & 46.559140 & -117.123971 & Covello & 0 & $\ldots$ & & \\
\hline $12^{v}$ & 19 Apr & Colton & 46.566088 & -117.113653 & Covello & 4,320 & filipjevi & $\mathrm{x}$ & $\mathrm{x}$ \\
\hline $13^{v}$ & 19 Apr & Colton & 46.566503 & -117.115023 & Covello & 240 & filipjevi & $\mathrm{x}$ & $\mathrm{x}$ \\
\hline 14 & $19 \mathrm{Apr}$ & Colton & 46.563779 & -117.099943 & Konert & 0 & $\ldots$ & & \\
\hline 15 & $19 \mathrm{Apr}$ & Uniontown & 46.545320 & -117.091122 & Covello & 9,240 & avenae & $\mathrm{x}$ & nt \\
\hline 16 & 19 Apr & Uniontown & 46.546788 & -117.083114 & Covello & 0 & $\ldots$ & & \\
\hline 17 & $19 \mathrm{Apr}$ & Uniontown & 46.527768 & -117.079373 & Palouse & 40 & nd & nt & nt \\
\hline 18 & $19 \mathrm{Apr}$ & Uniontown & 46.517569 & -117.079043 & Calouse & 40 & nd & nt & nt \\
\hline $19^{w}$ & $19 \mathrm{Apr}$ & Uniontown & 46.510019 & -117.067737 & Calouse & 0 & $\ldots$ & & \\
\hline 20 & 7 May & Uniontown & 46.542387 & -117.084547 & Covello & 132 & nd & $\mathrm{nt}$ & nt \\
\hline $21^{\mathrm{x}}$ & 7 May & Uniontown & 46.545208 & -117.091034 & Covello & 20,724 & avenae + filipjevi & $\mathrm{x}$ & $\mathrm{x}$ \\
\hline 22 & 7 May & Uniontown & 46.549679 & -117.095915 & Covello & 0 & $\ldots$ & & \\
\hline 23 & 7 May & Uniontown & 46.556655 & -117.103610 & Covello/Konert & 44 & nd & $\mathrm{nt}$ & nt \\
\hline 24 & 7 May & Colton & 46.560541 & -117.105165 & Covello & 6,864 & filipjevi & $\mathrm{x}$ & $\mathrm{x}$ \\
\hline 25 & 7 May & Colton & 46.564246 & -117.109119 & Konert & 0 & $\ldots$ & & \\
\hline 26 & 7 May & Colton & 46.563043 & -117.109340 & Covello & 3,300 & filipjevi & $\mathrm{x}$ & $\mathrm{x}$ \\
\hline 27 & 7 May & Colton & 46.565061 & -117.115507 & Covello & 704 & filipjevi & $\mathrm{x}$ & $\mathrm{x}$ \\
\hline $28^{y}$ & 7 May & Colton & 46.565995 & -117.113634 & Covello & 3,300 & filipjevi & $\mathrm{x}$ & $\mathrm{x}$ \\
\hline 29 & 7 May & Colton & 46.566312 & -117.113594 & Covello & 0 & $\ldots$ & & \\
\hline 30 & 7 May & Colton & 46.570472 & -117.134691 & Covello & 0 & $\ldots$ & & \\
\hline 31 & 7 May & Colton & 46.574555 & -117.142944 & Konert & 0 & $\ldots$ & & \\
\hline 32 & 7 May & Colton & 46.575774 & -117.149991 & Caldwell & 0 & $\ldots$ & & \\
\hline 33 & 7 May & Colton & 46.579607 & -117.154775 & Latah & 0 & $\ldots$ & & \\
\hline 34 & 7 May & Colton & 46.584413 & -117.160371 & Konert & 0 & $\ldots$ & & \\
\hline 35 & 7 May & Colton & 46.594286 & -117.185458 & Konert & 0 & $\ldots$ & & \\
\hline $36^{\mathrm{v}, \mathrm{z}}$ & 7 May & Pullman & 46.769602 & -117.274035 & Latah & 8,712 & avenae & $\mathrm{x}$ & $\mathrm{x}$ \\
\hline
\end{tabular}

${ }^{\mathrm{r}}$ Geographic coordinates are based upon Google Earth's World Geodetic System of 1984 (WGS84) datum imagery system.

${ }^{\mathrm{s}}$ Molecular identifications and confirmations of species identity using species-specific PCR assays and PCR-RFLP procedures; nt = not tested by DNAbased methods.

${ }^{t}$ All soils were silt loams within a closely related group of soil series developed on lowlands adjacent to streams. Most soils collected on 7 May were spaced at about 0.5- to 1-km intervals in fields adjacent to Union Flat Creek either south (\#19-28) or north (\#29-35) of the site initially determined to be infested by $H$. filipjevi (\#12 and \#28).

u Nematode density (Heterodera spp./kg of soil) includes juveniles extracted from soil plus eggs + juveniles from cysts extracted from soil.

${ }^{\vee}$ Sites of wheat cultivar screening trials during 2011, 2012, 2013, and/or 2014. Soils \#12 and \#28 were collected from the trial site that prompted this survey.

${ }^{\text {w }}$ Site previously confirmed to be infested by $H$. avenae $(45,48,52,67)$.

${ }^{x}$ Soil \#21 was from the same site as soil \#15.

${ }^{y}$ Soil \#28 was from the same site as soil \#12; wheat cultivar reactions to a Heterodera spp. from this site were reported previously in Figure 4 of Smiley et al. (48).

${ }^{\mathrm{z}}$ Wheat cultivar reactions to a Heterodera spp. from the site of soil \#36 were reported previously in Figure 3 of Smiley et al. (48). 
Females without an underbridge were considered to be $H$. avenae and females with an underbridge were considered to be $H$. filipjevi.

The experiment was repeated with a planting on 12 May using soils collected on 7 May; Table 1, Soil \#22 (no Heterodera spp.), \#28 (H. filipjevi), and \#36 (H. avenae). All procedures in the second repetition were the same as described for the first repetition except that the entire incubation was performed at $18^{\circ} \mathrm{C}$ and a $15-\mathrm{h}$ light interval, and the harvest date was at 406 degree days following seedling emergence.

Statistical analyses for resistance experiments. Genotypic growth differences and numbers of newly formed white females in the experiment with cv. Louise were analyzed using analysis of variance (ANOVA) and a 2-way randomized complete block design with experimental repetition and soil (Heterodera spp. or control) as treatments and replicates as blocks. ANOVA was performed using CoStat Statistical Software (Co-Stat v. 6.400, CoHort Software, Monterey, CA). When treatment means for plant height, shoot weight, root weight, or root/shoot ratio were significant at $\alpha$ $<0.05$, means were separated using the Tukey's honestly significant difference (HSD) test. Data are reported as the means and standard error of the means. Analyses of white females were performed on data normalized by using the $\ln (x+1)$ transformation, and logarithmic means were back-transformed for presentation. Means of ordinate data for root knotting severity were analyzed by the Kruskal-Wallis test. When the Pearson's chi-squared $\left(\chi^{2}\right)$ value for the experiment was significant at $\alpha<0.05$, the treatments were examined pair-wise to determine which treatments differed significantly. A 3-way ANOVA was performed for the two repetitions of the experiment in which the six cultivars were planted into three soils. Treatments were repetition, soil (Heterodera spp. or control), and cultivar. When the repetition effect was significant, the repetitions were analyzed separately using 2-way ANOVA, with soil and cultivar as main treatments. Finally, when the effect of soil (Heterodera spp. or the control) was significant, 1-way ANOVA was performed for each soil treatment, using cultivar as the treatment variable.

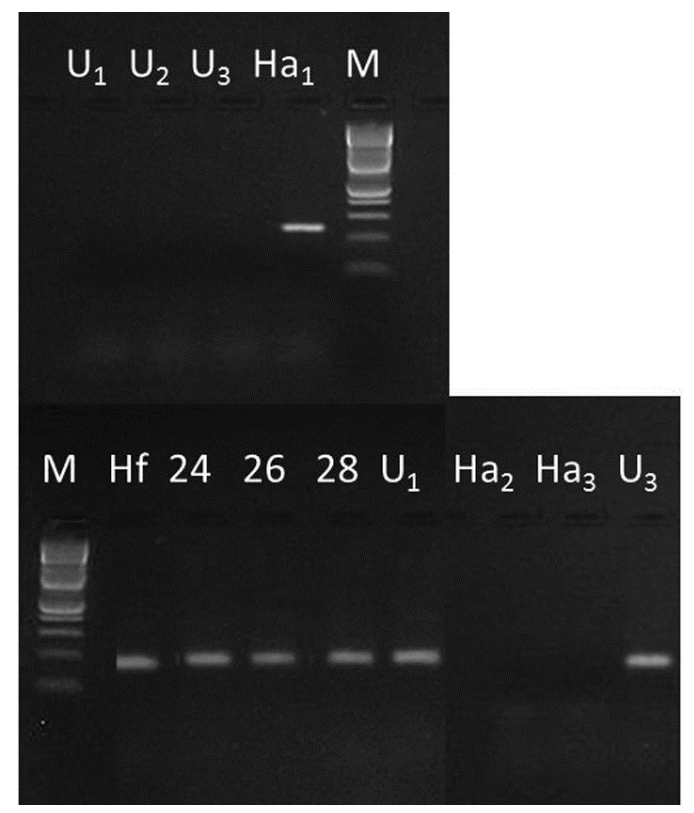

Fig. 1. Polymerase chain reaction (PCR) amplification of DNA from eggs taken from two brown cysts extracted from a soil sample from Colton, WA $\left(U_{1}\right.$ and $\left.U_{2}\right)$, one white female detached from a wheat root within that sample $\left(\mathrm{U}_{3}\right)$, and three newly collected soils from Colton, WA (Table 1; \#24, \#26, and \#28), compared to control populations of Heterodera filipjevi from Imbler, $\mathrm{OR}(\mathrm{Hf})$ and $\mathrm{H}$. avenae from Cove, $\mathrm{OR}\left(\mathrm{Ha}_{1}\right)$, St. Anthony, ID $\left(\mathrm{Ha}_{2}\right)$, and Palouse, WA $\left(\mathrm{Ha}_{3}\right)$. PCR bands are at $242 \mathrm{bp}$ using $H$. avenae primers (top) and at 170 bp using $H$. filipjevi primers (bottom); $M=$ 100-bp DNA molecular weight ladder. Extractions of DNA from eggs taken from unknown cysts $\left(U_{1-3}\right)$ in the original sample were from the same field as the newly collected Soil \#28.

\section{Results}

Identification of Heterodera species. Results of PCR assays indicated that the cysts from the initial sample were not $H$. avenae and were H. filipjevi (Fig. 1). These results were based upon eggs taken from cysts in soil as well as a cyst detached from a wheat root in the sample.

Based on species-specific PCR assays of 16 subsequent soil samples, six samples (\#12, \#13, \#24, \#26-28) near Colton, WA produced specific bands with the same size (170 bp) as the $H$. filipjevi-positive control and did not produce any amplification with the $H$. avenae primers. The PCR amplifications for three of the samples using the $H$. filipjevi primers are shown in Figure 1. Therefore, the nematode species in these samples were identified as entirely $H$. filipjevi (Table 1). Soil samples from eight samples (\#1-5, \#8, \#15, \#36) near Colfax, Pullman, and Uniontown, WA produced PCR bands with the same size (242 bp) as the $H$. avenae-positive control and did not show amplification using the $H$. filipjevi-specific primers, indicating that the nematode species in these samples were entirely $H$. avenae (Table 1 ). The first DNA extract from a cyst of sample \#6 near Colfax produced the H. filipjevi-specific band using the $H$. filipjevi primer pair, but the second DNA extract from juveniles extracted from soil of that same sample produced the $H$. avenae-specific band using the $H$. avenae primer pair. The DNA extracts from sample \#21 (Uniontown) produced the $H$. filipjevi-specific band plus the $H$. avenae-specific band when tested with the corresponding primers. These results indicated that soil samples \#6 and \#21 contained mixed populations of $H$. avenae and $H$. filipjevi (Table 1).

The species identity in 15 of the 16 soil samples was also examined by the PCR-RFLP restriction pattern (Figs. 2 to 4 ). The six soil samples identified as $H$. filipjevi by the species-specific PCR produced the same banding pattern as that of the $H$. filipjevi control but different from the controls of $H$. avenae, $H$. latipons, and $H$. schachtii, confirming the validity of the PCR assays (Table 1). The

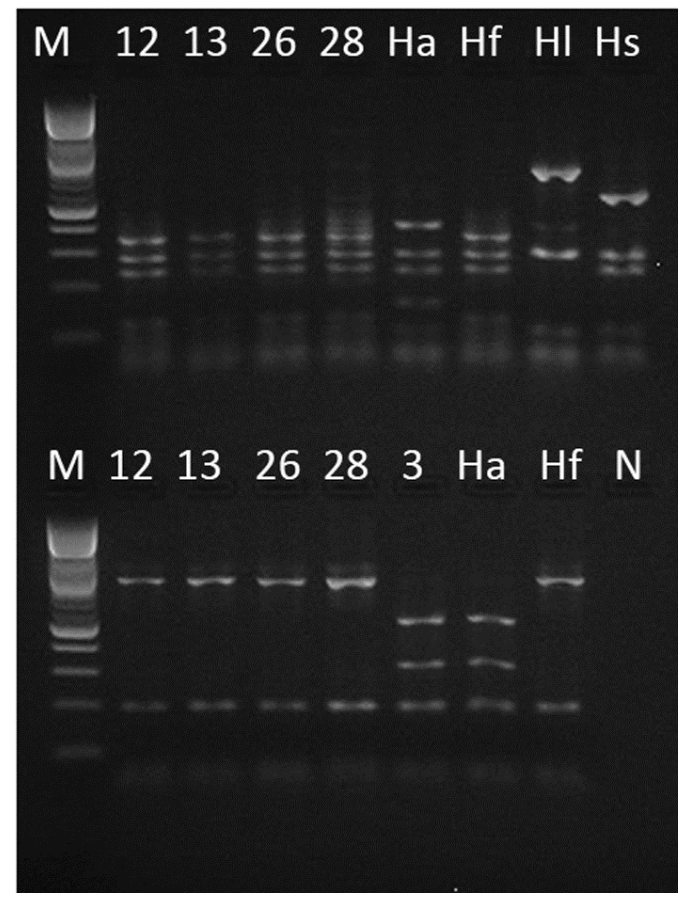

Fig. 2. Polymerase chain reaction-restriction fragment length polymorphism (PCRRFLP) patterns for DNA of Heterodera spp. extracted from five soil samples and digested with two restriction endonucleases (top: Taql; bottom: Hinf), as compared to control populations of $H$. avenae from St. Anthony, ID $(\mathrm{Ha}), H$. filipjevi from Imbler, OR (Hf), H. latipons from Iran (HI), H. schachtii from France (Hs), a 100-bp molecular weight DNA ladder (M), and a negative control without DNA (N). Soil sample origins (Table 1) were soil \#12 (Colton, WA), soil \#13 (Colton, WA), soil \#26 (Colton, WA), soil \#28 (Colton, WA), and soil \#3 (Colfax, WA). 
seven soil samples identified as $H$. avenae produced the same banding pattern as that of the $H$. avenae DNA standard and different from that of $H$. filipjevi, again consistent with results of the PCR assays. The first DNA extract from sample \#6 showed the same banding pattern as that of the $H$. filipjevi control, but the second DNA extract showed the same banding pattern as the $H$. avenae control. Sample \#21 showed a type of banding pattern different from that of the control sample of $H$. filipjevi or $H$. avenae but exhibited the same restriction pattern as the mixture of the control samples of $H$. filipjevi and $H$. avenae when digested with Hinf and RsaI (Figs. 3 and 4). These PCR-RFLP results confirmed that samples \#6 and \#21 had mixed populations of $H$. avenae and $H$. filipjevi (Table 1). Intraspecific polymorphism was observed between the four $H$. avenae populations from Pullman and Colfax, WA using RsaI digestion (Fig. 3).

Species identity in six soil samples (\#6, \#12,\#15, \#24, \#26, and \#28) was also confirmed by cyst morphology. The cuticles of mature cysts in samples \#12, \#24, \#26, and \#28 were golden- to lightbrown in color, which is similar to that of $H$. filipjevi. The cuticle of mature cysts in sample \#15 was dark-brown to black, which is similar to $H$. avenae. A mixture of light-brown and dark-brown cysts was found in sample \#6. The vulval cones in $H$. filipjevi cysts (\#6, \#12, \#24, \#26, and \#28) had a well-developed underbridge with bifurcated arms, the semifenestrae were horseshoe shaped, and bullae were small to medium in size and light to medium brown in color. The vulval cones in $H$. avenae cysts (\#6 and \#15) had no underbridge, the semifenestrae were oval, and bullae were well developed, numerous, and dark brown, impeding the observation of the fenestral structure.

The consensus sequence data were obtained from both directions of sequencing of the ITS region of rDNA from two $\mathrm{H}$. filipjevi populations (soils \#12 and \#26). The nucleotide blast analysis with known sequences in the GenBank showed that the $H$. filipjevi sequences from Colton, WA were identical to the ITS sequence of $H$. filipjevi from Imbler, OR (GU079654) and the ITS sequences of at least $13 \mathrm{H}$. filipjevi isolates from other countries (GU083595,

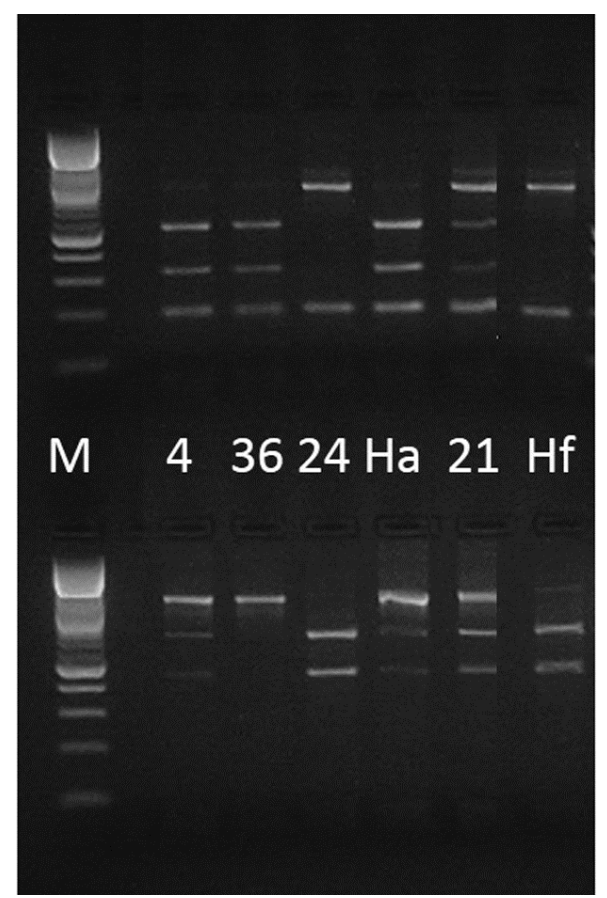

Fig. 3. Polymerase chain reaction-restriction fragment length polymorphism (PCRRFLP) patterns for DNA of Heterodera spp. extracted from four soil samples and digested with two restriction endonucleases (top: Hinf; bottom: Rsal), as compared to control populations of $H$. filipjevi from Imbler, $\mathrm{OR}(\mathrm{Hf})$ and $H$. avenae from Colfax, WA (Ha), and a 100-bp molecular weight DNA ladder (M). Soil sample origins (Table 1) were soil \#4 (Colfax, WA), soil \#36 (Pullman, WA), soil \#24 (Colton, WA), and soil \#21 (Uniontown, WA).
AY347922, AY148403, AY148402, AF274399, AY148397, AY148398, JX024205, JX024206, JX024203， JX235959, JX024207, KF225725). The target $H$. filipjevi also showed 99\% sequence similarity with at least 24 other isolates of $H$. filipjevi. However, it had 4 to $5 \%$ sequence dissimilarity with all $H$. avenae isolates in the distribution of 100 blast hits on the query sequence except one from China (KF679395). The Colton H. filipjevi populations had at least 21 nucleotides that were different than some closely related species in the $H$. avenae group, including at least 99 isolates of $H$. avenae, 1 isolate of $H$. arenaria (4\% sequence divergence), 3 isolates of $H$. ustinovi (3\%), 6 isolates of $H$. australis (4 to $5 \%), 10$ isolates of $H$. pratensis ((4 to 5\%), 5 isolates of $H$. mani (4 to $5 \%$ ), and 2 isolates of $H$. aucklandica (5\%). Sequence divergence for the Colton $H$. filipjevi with 3 isolates of $H$. bifenestra, 7 isolates of $H$. hordecalis, and 28 isolates of $H$. latipons was 8 to $13 \%$. The sequences of one $H$. avenae population from Pullman, WA (soil \#36) showed $100 \%$ identity with the $H$. avenae isolate from Idaho (EF153843) and 99 to $100 \%$ identity with all of the $H$. avenae isolates in the distribution of 100 blast hits on the query sequence. The target $H$. avenae sequences had 23 nucleotides that were different than that of the $H$. filipjevi isolate from Oregon (GU079654), demonstrating 3\% sequence dissimilarity.

Distribution and population density. In the 19 April sampling, Heterodera spp. were detected in 14 of 19 sites (74\%) sampled in Whitman County, WA (Table 1). Subsequent molecular and morphological examinations of 11 of the 14 Heterodera-positive samples from Whitman County indicated that eight were $H$. avenae. Two samples collected near Colton were identified as $H$. filipjevi based on molecular testing and the presence of an underbridge in the vulval cone. One sample collected between Pullman and Colfax (\#6) was determined to be infested with a mixture of $H$. avenae and $H$. filipjevi. Species identity in three samples with low densities of Heterodera spp. was not determined due to the scarcity of Heterodera spp. in those samples. These samples harbored a range of nematode population densities, from 0 to 9,240 Heterodera spp. eggs and juveniles $/ \mathrm{kg}$ of soil, based on data from Western Laboratories (Table 1). Population densities exceeded 1,000 Heterodera spp./kg of soil in seven of the 14 fields $(50 \%)$ sampled in Whitman County, WA. Pratylenchus spp. (root-lesion nematode) were detected in 17 of 19 samples (89\%) collected from Whitman County on 19 April; densities ranged from 40 to 1,680 nematodes $/ \mathrm{kg}$ of soil (data not presented). Tylenchorhynchus spp. (stunt nematode) was detected in five samples (from 40 to $840 / \mathrm{kg}$ of soil) and Paratylenchus spp. (pin nematode) was detected at a low density (120/kg of soil) in one sample.

Eight of 17 fields (47\%) sampled in Whitman County on 7 May contained Heterodera spp. (Table 1). Seven infested fields were between Colton and Uniontown, and all were classified as Covello silt loam. One field was north of Pullman and classified as Latah silt loam. Molecular and morphological examinations of six of the eight Heterodera-positive samples indicated that four were infested only by $H$. filipjevi, one was infested only by $H$. avenae, and one

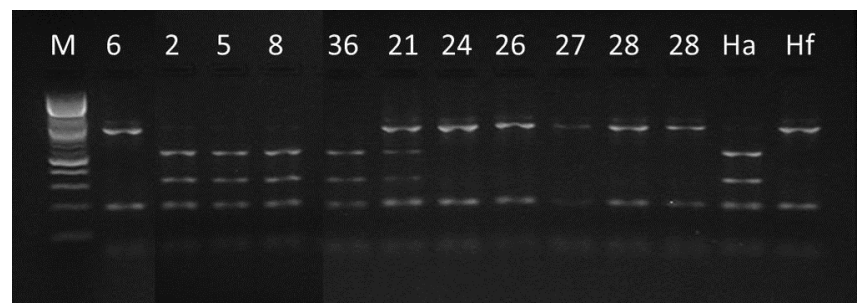

Fig. 4. Polymerase chain reaction-restriction fragment length polymorphism (PCRRFLP) patterns for DNA of Heterodera spp. extracted from 11 soil samples and digested with the Hinf restriction endonuclease, as compared to control populations of $H$. avenae from St. Anthony, ID (Ha) and of $H$. filipjevi from Imbler, OR (Hf), and a 100-bp molecular weight DNA ladder (M). Soil sample origins (Table 1) were soil \#6 (Colfax, WA), soil \#2 (Colfax, WA), soil \#5 (Colfax, WA), soil \#8 (Pullman, WA), soil \#36 (Pullman, WA), soil \#21 (Uniontown, WA), soil \#24 (Colton, WA), soil \#26 (Colton, WA), soil \#27 (Colton, WA), and soil \#28 (Colton, WA). 
was infested by a mixture of these species (Table 1). The sample from the field shown previously to be infested by H. filipjevi (Table 1, \#12 and \#28) was again shown to contain H. filipjevi. These 17 samples harbored nematode densities ranging from 0 to 20,724 Heterodera spp. eggs and juveniles $/ \mathrm{kg}$ of soil, based on data from Western Laboratories (Table 1). Five of the 17 samples collected on 7 May had population densities greater than 3,000 Heterodera $\mathrm{spp} . / \mathrm{kg}$ of soil. No Heterodera spp. were detected in nine samples collected in the Union Flat Creek drainage over a 4.7-km distance north of Colton, where the soils were all closely related silt loams in the Covello, Konert, Latah, and Caldwell series. Species of Pratylenchus, Tylenchorhynchus, and Paratylenchus spp. were also detected in 16, 11, and 3 of the 17 fields sampled on 7 May. Moderate to high densities of Pratylenchus spp. (1,320 to 4,200/kg of soil) occurred in five samples (\#20, \#23, \#25, \#29-30), and moderate to high densities of Tylenchorhynchus spp. (360 to $1,680 / \mathrm{kg}$ of soil) occurred in four samples (\#24-26, \#30). There was no apparent relationship between occurrence or density of Heterodera spp. and Pratylenchus spp. (data not presented).

Virulence of Heterodera spp. to spring wheat cv. Louise. $H$. avenae and $H$. filipjevi were each virulent on Louise. More than 20 white females were formed on roots of each plant examined (Table 2). Numbers of white females/root system did not differ among repetitions $(P=0.7765)$ or between $H$. avenae and H. filipjevi (Table 2), and the interaction between experimental repetition and Heterodera spp. was not significant $(P=0.8291)$. No white females or old brown cysts were detected in the control soil. Newly formed white cysts recovered from roots and evaluated for presence or absence of an underbridge in the vulval cone confirmed that identity of all examined cysts in each soil were consistent with the soils that had been determined to be infested by either $H$. avenae or $H$. filipjevi. The severity of the root knotting symptom differed significantly between repetitions, soil treatments, and for the repetition $\times$ soil interaction at $P<0.0001$. Severity ratings averaged 1.0, 4.5, and 4.5 for the noninfested control soil and the soils infested with $H$. avenae and $H$. filipjevi, respectively (Table 2). Plant height differed significantly between experiments and soils, and the repetition $\times$ soil interaction was not significant. Average height was greater (56 versus $45 \mathrm{~cm}$ ) during the second than the first repetition, likely reflecting the greater number of growing degree days before the second repetition was harvested. Averaged over both repetitions, plant height was less in Heterodera-infested soil than in noninfested soil (Table 2). Shoot weight and root weight were significantly lower in soil infested by $H$. filipjevi than in soil infested by $H$. avenae, and the latter did not differ from the noninfested control soil (Table 2). Neither shoot weight nor root weight differed significantly between repetitions, nor was the repetition $\times$ soil interaction significant for either of these parameters. These data indicated that both pathogens were virulent on Louise and that plant growth differences occurred among soils, presumably because the soils were collected from fields that were likely to have been managed differently. We concluded that Louise could serve as the susceptible control for the subsequent cultivar experiment.

Virulence of Heterodera spp. to six spring wheat cultivars. Data for the noninfested control soil treatment were analyzed separately to determine if differences in growth occurred as a result of soil treatment. The treatment effect for plant height was significant $(P<0.0001)$ for experimental repetition and cultivar. Repetition was also significant for shoot weight and root weight, and cultivar was significant for shoot weight but not for root weight. The repetition $\times$ cultivar interaction was significant for plant height but not for shoot weight or root weight. These relationships indicated that plant growth was greater in the second than in the first repetition; 43.5 and $40.4 \mathrm{~cm}$, respectively $\left(\mathrm{HSD}_{0.05}=1.4\right)$. Mean plant height was 47, 44, 42, 41, 39, and $38 \mathrm{~cm}$ for Sönmez, WB 936, SY Steelhead, Louise, WB Rockland, and Ouyen, respectively $\left(\mathrm{HSD}_{0.05}=\right.$ 2.4). Mean plant height was 45,41 , and $40 \mathrm{~cm}$ for the noninfested soil and soils infested with $H$. avenae and $H$. filipjevi $\left(\mathrm{HSD}_{0.05}=\right.$ 1.7), respectively, indicating a stunting effect from invasion of CCN. Mean shoot weight was 372, 312, and $243 \mathrm{mg} / \mathrm{plant}$ for the noninfested soil and soils infested with $H$. avenae and $H$. filipjevi, respectively $\left(\mathrm{HSD}_{0.05}=27\right)$, again indicating suppression of growth by these Heterodera spp. Likewise, mean root weight was 279 , 191, and $194 \mathrm{mg} /$ plant for the noninfested soil and soils infested with $H$. avenae and $H$. filipjevi, respectively $\left(\mathrm{HSD}_{0.05}=26\right)$.

Experimental parameters of greatest interest in the 6-cultivar assay were those associated with disease symptoms and signs. The incidence of root abnormalities characteristic of invasion by Heterodera spp. was $100 \%$ for each cultivar and each Heterodera spp. in each repetition of the experiment (data not shown). No root abnormality or swollen white females of Heterodera spp. were detected in any cultivar in the control soil. As in the previous assay with cv. Louise, evaluation of vulval cones of all newly formed white cysts confirmed the accuracy of species identity in each soil. Assay conditions were therefore considered favorable for comparing the six cultivars.

In the first repetition, root disease severity and numbers of swollen white females were each significantly less on Ouyen and WB Rockland than on Louise in soil infested by $H$. avenae, and were less on Sönmez and SY Steelhead than on Louise, WB 936, and WB Rockland in soil infested by H. filipjevi (Table 3). In the second repetition, root disease severity ratings did not differ among cultivars in soils infested with $H$. avenae or $H$. filipjevi (Table 3 ). As in the first repetition, the number of white females in soil infested with $H$. avenae was significantly lower for Ouyen and WB Rockland than for the other four cultivars. In soil infested with $H$. filipjevi, the number of white females was lower for Sönmez and SY Steelhead than for Louise, WB Rockland, and WB 936.

Ouyen and WB Rockland were characterized as resistant to $H$. avenae in both repetitions (Table 3). Sönmez was characterized as resistant to $H$. filipjevi in both repetitions, and SY Steelhead was rated as moderately resistant to $H$. filipjevi in both repetitions. Louise and WB936 were susceptible to both Heterodera spp.

Table 2. Plant growth, root knotting severity, and number of Heterodera avenae or H. filipjevi white females produced on roots of spring wheat cultivar Louise in naturally infested soils ${ }^{\mathrm{w}}$ or noninfested soil incubated in a growth chamber

\begin{tabular}{|c|c|c|c|c|c|c|}
\hline Parameter & H. avenae & H. filipjevi & Control & $P>F$ & CV $(\%)$ & HSD $_{0.05}$ \\
\hline Plant height $(\mathrm{cm})$ & $50.7 \pm 4.4 \mathrm{~b}^{\mathrm{x}}$ & $46.7 \pm 3.5 \mathrm{c}$ & $54.7 \pm 3.8 \mathrm{a}$ & 0.0004 & 4.4 & 2.9 \\
\hline Shoot wt. (mg) & $1,012 \pm 164.0 \mathrm{a}$ & $454.3 \pm 35.8 b$ & $1,090.7 \pm 94.1 \mathrm{a}$ & 0.0011 & 26.3 & 287.8 \\
\hline Root wt. (mg) & $483 \pm 78.5 \mathrm{a}$ & $256.0 \pm 16.2 \mathrm{~b}$ & $549.7 \pm 35.2 \mathrm{a}$ & 0.0007 & 21.7 & 120.0 \\
\hline RK Sever $(1-5)^{\mathrm{y}}$ & $4.5 \pm 0.3 \mathrm{a}$ & $4.5 \pm 0.3 \mathrm{a}$ & $1.0 \pm 0.0 \mathrm{~b}$ & $<0.0001$ & 9.5 & 0.4 \\
\hline White females/plant ${ }^{\mathrm{Z}}$ & $23.4 \pm 2.2 \mathrm{a}$ & $36.7 \pm 4.1 \mathrm{a}$ & $0.0 \pm 0.0 \mathrm{~b}$ & $<0.0001$ & 3.2 & na \\
\hline
\end{tabular}

${ }^{\text {w }}$ Soils were Covello silt loams collected on two separate occasions from three fields located within $3 \mathrm{~km}$ of one another. Trial 1: Soil infested with $H$. avenae (Table 1, soil \#15), H. filipjevi (\#12), or with neither species (\#11). Trial 2: Soil infested with H. avenae (\#36), only with $H$. filipjevi (\#28), or with neither species (\#22).

${ }^{x}$ Data are means and standard error of the mean grouped over two repetitions of the experiment; $n=6$, with 3 replicates per treatment in each repetition. Means within rows followed by the same letter did not differ significantly at $\alpha=0.05$ as determined by Tukey's honestly significant difference (HSD) test.

${ }^{\mathrm{y}} \mathrm{RK}$ Sever $=$ root disease severity rating scaled as $1=$ no evidence of damage, $2=1$ to 3 knots/root system, $3=3$ to 5 knots, $4=>5 \mathrm{knots}$ and $<20 \%$ reduction in plant height or root mass, and $5=>5$ knots and $>20 \%$ reduction in plant height or root mass.

${ }^{\mathrm{z}}$ Number of white females per plant, back-transformed means from analyses performed using the $\ln (x+1)$ transformation; na $=$ the HSD test is not applicable to analyses performed on transformed data. 


\section{Discussion}

We report here the largest and most pure cluster of $H$. filipjeviinfested fields currently known to exist in the United States. A specimen from one field in the cluster was initially identified using species-specific PCR (67). This cluster of fields in Washington is only the second location where $H$. filipjevi has been detected in North America $(51,64)$. This report therefore establishes the presence of $H$. filipjevi in at least two states, and is particularly important because Whitman County, WA produces a greater quantity of wheat than any other county in the United States (61). Greater emphasis on managing both $H$. avenae and $H$. filipjevi is therefore warranted. Much research on fields infested with $H$. avenae has already been conducted in the PNW $(43,45,46,48,50,52)$, and extensive research on both species has been conducted in other regions of the world $(5,28,33,35,49,60)$.

Samples from two fields surveyed for this research (Table 1, \#6 and \#21) were found to have mixed populations of $H$. avenae and $H$. filipjevi. Additional research is needed to clarify the characteristics of these mixtures. Although it is common for mixtures of these Heterodera spp. to occur worldwide $(1,15,37,65)$, re-confirmation of the apparent mixture in soil \#6 (near Colfax, WA) is particularly important because it is located $35 \mathrm{~km}$ north of the cluster of $H$. filipjevi-infested fields near Colton, WA. If confirmed, the presence of $H$. filipjevi in at least two locations of Whitman County would suggest that there is a potential for $H$. filipjevi to be found at even more locations. Increases in grain yield have been achieved in Norway in response to linking the release of cultivars with resistance to either $H$. avenae or $H$. filipjevi with diagnostic services that have identified the Heterodera spp. (15). Holgado et al. (15) reported an average yield increase of $1,000 \mathrm{~kg} / \mathrm{ha}$ in one Norwegian county within 3 years after growers began to use the linkage of diagnostic services with germplasm improvement services on fields infested with $H$. avenae, $H$. filipjevi, or mixtures of these species.

We anticipate that $H$. filipjevi will be detected in additional locations and states when newly developed species-specific PCR diagnostic tests $(59,67)$ are used routinely in commercial nematode testing laboratories. In the past, these laboratories have enumerated Heterodera in thousands of samples annually, but they typically quantified them as members of the $H$. avenae Group, without naming the specific species due to the difficulty, time, and expense previously required to distinguish these species using morphological metrics $(14,63)$ or DNA-based tests such as PCR-RFLP

Table 3. Root knotting severity, number of Heterodera avenae or $H$. filipjevi white females produced on roots, and nematode resistance ratings of six spring wheat cultivars using naturally infested soils ${ }^{\mathrm{v}}$ that were incubated in a growth chamber; two repetitions of these assays are reported individually

\begin{tabular}{|c|c|c|c|c|c|c|c|c|}
\hline $\begin{array}{l}\text { Parameter } \\
\text { and tested pathogen }\end{array}$ & Louise & Ouyen & WB 936 & WB Rockland & Sönmez & SY Steelhead & HSD $_{0.05}$ & $P>F$ \\
\hline \multicolumn{9}{|l|}{ First repetition: } \\
\hline \multicolumn{9}{|l|}{ RK Severity ${ }^{\mathrm{w}}(1-5)$} \\
\hline H. avenae & $4.7 \pm 0.3 \mathrm{a}^{\mathrm{x}}$ & $3.3 \pm 0.3 b$ & $4.0 \pm 0.0 \mathrm{ab}$ & $3.0 \pm 0.0 \mathrm{~b}$ & $3.7 \pm 0.3 \mathrm{ab}$ & $4.0 \pm 0.0 \mathrm{ab}$ & 0.7 & 0.0059 \\
\hline H. filipjevi & $4.3 \pm 0.3 \mathrm{a}$ & $4.0 \pm 0.6 \mathrm{ab}$ & $4.3 \pm 0.3 \mathrm{a}$ & $4.7 \pm 0.3 \mathrm{a}$ & $2.3 \pm 0.3 b c$ & $1.3 \pm 0.3 \mathrm{c}$ & 1.2 & 0.0003 \\
\hline Control & $1.0 \pm 0.0 \mathrm{a}$ & $1.0 \pm 0.0 \mathrm{a}$ & $1.0 \pm 0.0 \mathrm{a}$ & $1.0 \pm 0.0 \mathrm{a}$ & $1.0 \pm 0.0 \mathrm{a}$ & $1.0 \pm 0.0 \mathrm{a}$ & ns & na \\
\hline \multicolumn{9}{|l|}{ White females } \\
\hline \multicolumn{9}{|l|}{ No./plant ${ }^{\mathrm{y}}$} \\
\hline H. avenae & $30.5 \pm 8.3 \mathrm{a}$ & $0.8 \pm 0.6 \mathrm{~b}$ & $19.8 \pm 5.3 \mathrm{a}$ & $0.6 \pm 0.3 b$ & $15.3 \pm 4.5 \mathrm{a}$ & $20.5 \pm 2.0 \mathrm{a}$ & na & $<0.0001$ \\
\hline H. filipjevi & $36.8 \pm 2.5 \mathrm{ab}$ & $12.3 \pm 5.9 \mathrm{bc}$ & $54.1 \pm 14.8 \mathrm{a}$ & $30.9 \pm 1.5 \mathrm{ab}$ & $1.3 \pm 0.9 \mathrm{~d}$ & $3.2 \pm 0.9 \mathrm{~cd}$ & na & $<0.0001$ \\
\hline Control & $0.0 \pm 0.0 \mathrm{a}$ & $0.0 \pm 0.0 \mathrm{a}$ & $0.0 \pm 0.0 \mathrm{a}$ & $0.0 \pm 0.0 \mathrm{a}$ & $0.0 \pm 0.0 \mathrm{a}$ & $0.0 \pm 0.0 \mathrm{a}$ & $\mathrm{ns}$ & na \\
\hline \multicolumn{9}{|c|}{ Compared to Louise (\%) } \\
\hline H. avenae & 100 & 3 & 65 & 2 & 50 & 67 & & \\
\hline H. filipjevi & 100 & 33 & 147 & 84 & 4 & 9 & & \\
\hline \multicolumn{9}{|l|}{ Resistance rating $^{z}$} \\
\hline H. avenae & VS & $\mathrm{R}$ & VS & $\mathrm{R}$ & $\mathrm{S}$ & $\mathrm{S}$ & & \\
\hline H. filipjevi & VS & S & VS & VS & $\mathrm{R}$ & MR & & \\
\hline \multicolumn{9}{|l|}{$\begin{array}{l}\text { Second repetition: } \\
\text { RK Severity (1-5) }\end{array}$} \\
\hline H. avenae & $4.3 \pm 0.3 \mathrm{a}^{\mathrm{x}}$ & $3.3 \pm 0.3 \mathrm{a}$ & $4.7 \pm 0.3 \mathrm{a}$ & $3.3 \pm 0.3 \mathrm{a}$ & $4.3 \pm 0.3 \mathrm{a}$ & $4.0 \pm 1.0 \mathrm{a}$ & $\mathrm{ns}$ & 0.0597 \\
\hline H. filipjevi & $4.3 \pm 0.7 \mathrm{a}$ & $4.7 \pm 0.3 \mathrm{a}$ & $4.3 \pm 0.3 \mathrm{a}$ & $4.7 \pm 0.3 \mathrm{a}$ & $4.0 \pm 1.0 \mathrm{a}$ & $3.3 \pm 0.3 \mathrm{a}$ & $\mathrm{ns}$ & 0.2890 \\
\hline Control & $1.0 \pm 0.0 \mathrm{a}$ & $1.0 \pm 0.0 \mathrm{a}$ & $1.0 \pm 0.0 \mathrm{a}$ & $1.0 \pm 0.0 \mathrm{a}$ & $1.0 \pm 0.0 \mathrm{a}$ & $1.0 \pm 0.0 \mathrm{a}$ & ns & na \\
\hline \multicolumn{9}{|l|}{ White females } \\
\hline \multicolumn{9}{|l|}{ No./plant } \\
\hline H. avenae & $36.1 \pm 5.8 \mathrm{a}$ & $1.3 \pm 0.3 b$ & $23.7 \pm 3.7 \mathrm{a}$ & $1.9 \pm 0.6 b$ & $32.0 \pm 6.5 \mathrm{a}$ & $31.2 \pm 2.3 \mathrm{a}$ & na & $<0.0001$ \\
\hline H. filipjevi & $84.0 \pm 7.6 \mathrm{a}$ & $25.8 \pm 2.5 \mathrm{ab}$ & $38.6 \pm 5.4 \mathrm{a}$ & $30.2 \pm 9.4 \mathrm{a}$ & $4.2 \pm 1.7 \mathrm{c}$ & $8.2 \pm 3.3 b c$ & na & 0.0002 \\
\hline Control & $0.0 \pm 0.0 \mathrm{a}$ & $0.0 \pm 0.0 \mathrm{a}$ & $0.0 \pm 0.0 \mathrm{a}$ & $0.0 \pm 0.0 \mathrm{a}$ & $0.0 \pm 0.0 \mathrm{a}$ & $0.0 \pm 0.0 \mathrm{a}$ & ns & na \\
\hline \multicolumn{9}{|c|}{ Compared to Louise (\%) } \\
\hline H. avenae & 100 & 4 & 66 & 5 & 89 & 86 & & \\
\hline H. filipjevi & 100 & 31 & 46 & 40 & 5 & 10 & & \\
\hline \multicolumn{9}{|l|}{ Resistance rating } \\
\hline H. avenae & VS & $\mathrm{R}$ & VS & $\mathrm{R}$ & VS & VS & & \\
\hline H. filipjevi & VS & $\mathrm{S}$ & $\mathrm{S}$ & $\mathrm{S}$ & $\mathrm{R}$ & MR & & \\
\hline
\end{tabular}

${ }^{v}$ Soils used in the first repetition were Covello silt loams collected from three different fields in Whitman County, WA that were infested with $H$. avenae (Table 1, soil \#3), with H. filipjevi (\#12), or neither species (\#11). Soils in the second repetition were a Latah silt loam infested with $H$. avenae (Table 1, soil \#36) and Covello silt loams infested with H. filipjevi (\#28) or with neither species (\#22).

${ }^{\mathrm{w}}$ RK Severity $=$ severity rating scaled as $1=$ no evidence of damage, $2=1$ to 3 knots/root system, $3=3$ to 5 knots, $4=>5$ knots and $<20 \%$ reduction in plant height or root mass, and $5=>5$ knots and $>20 \%$ reduction in plant height or root mass.

${ }^{x}$ Means plus standard error of the mean; $n=3$. Means for plant growth parameter and of white females/root, followed by the same letter within a column, did not differ significantly at $\alpha=0.05$ as determined by Tukey's honestly significant difference (HSD) test; ns $=$ not significant. Means of severity data for the root knot symptom were analyzed by the Kruskal-Wallis test. When the Pearson's $\chi^{2}$ value for the experiment was significant at $\alpha<0.05$, treatments were examined pair-wise to determine which treatments differed significantly.

y Mean number and standard error of the mean for white females produced on roots of each plant, based upon means back-transformed from analyses performed using the $\ln (x+1)$ transformation, and white females produced on each cultivar as a percentage of those produced on $\mathrm{cv}$. Louise; na = the HSD test is not applicable to analyses performed on transformed data.

${ }^{\mathrm{z}}$ Phenotypic resistance reaction (25); $\mathrm{VR}=$ resistant $(\leq 1 \%$ of white females produced on susceptible control, cv. Louise in this study), $\mathrm{R}=$ resistant $(1.1$ to $5 \%), \mathrm{MR}=$ moderately resistant $(5.1$ to $15 \%), \mathrm{MS}=$ moderately susceptible $(15.1$ to $30 \%), \mathrm{S}=$ susceptible $(30.1$ to $60 \%)$, VS $=$ very susceptible $(>60 \%)$. 
$(1,6,26,36,53-55,57,65)$. It is fortuitous that recent development of less expensive and more rapid PCR tests $(59,67)$ has occurred at the time when identifying individual species of Heterodera in PNW soils has also become more important. One laboratory that processes soil samples from throughout the western United States recently expanded their testing services to include species-specific PCR assays to distinguish the most important species occurring on small grains in the PNW, including $H$. avenae, $H$. filipjevi, Pratylenchus neglectus, and $P$. thornei (Harry Kreeft, Western Laboratories, Parma, ID, personal communication). The tests at Western Laboratories were derived from protocols reported by Yan et al. (66-69). The availability of a DNA-based species-specific commercial service is likely to greatly expand information on the geographic distribution of $H$. filipjevi in the PNW. This will become very important for wheat producers who will need that information to develop management plans on soils found to be infested with either $H$. avenae or $H$. filipjevi.

Intraspecific variation was detected among populations of $H$. avenae from Pullman and Colfax during this sampling of fields in Whitman County, WA. Variation in $H$. avenae was detected using the RsaI restriction endonuclease. However, our tests were too limited to provide surety of this finding. Additional testing is warranted because we reported earlier that we found no evidence of intraspecific variation among multiple populations of $H$. avenae from Idaho, Oregon, and Washington (65). At that time, only one $H$. avenae population from Washington (nearest city: Palouse) was evaluated for intraspecific polymorphism (65). Genetic diversity among $H$. avenae populations from Washington would be revealed with more testing of infested fields based on the finding reported in this study.

An important finding during this study was that the Heterodera species named for one of the locations reported in a recent manuscript (48) was erroneous. Difficulties in distinguishing $H$. avenae and $H$. filipjevi have been common since these species were separated in 1981 and that distinction became accepted during the following two decades $(14,37,49)$. As a recent example, the authors of this paper considered all populations of cereal cyst nematodes in Oregon to be $H$. avenae until the application of molecular tests revealed that an Oregon population from Imbler was $H$. filipjevi $(51,64,65)$. Specific to research reported in this paper, Figure 4 in Smiley et al. (48) describes data from a field trial where resistance to a CCN was evaluated at a site near Colton, WA during 2012, where ' $H$. avenae' was reported as the species at that site. During 2012, 40 cultivars in the Western Regional Hard and Soft Spring Wheat Nurseries were evaluated at that location, including seven commercial cultivars and 33 advanced breeding lines from publicand private-sector breeding programs. Figure 4 of Smiley et al. (48) reports SY-97621-05 (now registered as SY Steelhead) as resistant to ' $H$. avenae'. Results of three separate samplings from around and within that screening site and from nearby fields during 2014 are reported in this paper. We found the site near Colton to be heavily infested with $H$. filipjevi during all three samplings, and we never detected $H$. avenae in the trial field or adjacent fields. Moreover, virulence assays performed in this study indicate that SY Steelhead is moderately resistant to $H$. filipjevi but not to $H$. avenae. We are now confident that the resistance of SY Steelhead to $\mathrm{CCN}$ at Colton, WA during 2012 and during subsequent years was evaluated in soil infested by $H$. filipjevi rather than by $H$. avenae. Current and future cultivar screening trials being conducted at that site should now be interpreted in accordance with the new finding of identification of $H$. filipjevi at the Colton, WA screening site.

The nature and origin of SY Steelhead's resistance to $H$. filipjevi is unknown. This cultivar was developed by the AgriPro cereal improvement program, which is a component of Syngenta Cereals, Berthoud, CO. The pedigree of SY Steelhead is B95-0136 (ANB/5/ EREN/RAP/3/JAR//SON/KLRE/4/MAB/6/BOMB/LNI)/SCAB23-1 (THB/SEP7780//SUZG/WEAVER//NING8675).

We also found Sönmez to be resistant to $H$. filipjevi, confirming previous reports of moderate resistance of Sönmez to $H$. filipjevi in
Turkey (38). In the work that we report here, Sönmez was susceptible to two populations of $H$. avenae from Whitman County, WA. In field trials during 2011, Sönmez also failed to reduce the postharvest density of $H$. avenae at three locations in Idaho, Oregon, and Washington (48). During field trials in 2011, Heterodera species at each of the three locations evaluated directly by the authors of this paper were confirmed to be $H$. avenae through the use of molecular and morphological methods (48). Sönmez was also susceptible to the Idaho population of $H$. avenae in a more-recent greenhouse assay (45). Smiley et al. (48) concluded that testing of Sönmez should be curtailed because that cultivar did not appear to be a useful resource for improving wheat tolerance or resistance to $H$. avenae in the PNW, and because only a few fields in Oregon were known at that time to be infested by a mixture of $H$. filipjevi and $H$. avenae. We suggested (48) that Sönmez may become a future resource for further evaluation if $H$. filipjevi was detected at other locations. It is now clear and important that Sönmez and SY Steelhead should be incorporated into wheat breeding programs in which cultivars that greatly reduce the reproductive capacity of $H$. filipjevi will be developed. The goal will be to pyramid genes for resistance to both $H$. avenae and $H$. filipjevi into breeding lines that will be released for production in $\mathrm{CCN}$-infested fields. It is also important to identify and characterize the genes for resistance to $H$. filipjevi in Sönmez and SY Steelhead, and to develop molecular markers that can increase the efficiency of wheat breeding programs in Oregon and Washington.

We indicated earlier that both Louise and WB 936 were included in our assays because they were previously found to be susceptible to PNW populations of $H$. avenae $(45,48)$ and had unknown reactions to $H$. filipjevi. In view of the finding of an incorrect species designation of Heterodera at Colton, WA in our previous report (48), we now know that Louise was previously found, in 2012, to be susceptible to $H$. filipjevi. Results of assays reported in this paper confirm the susceptibility of Louise to $H$. filipjevi and report that WB 936, Ouyen, and WB Rockland are also susceptible to $H$. filipjevi. The current assays also confirm previous reports that Ouyen and WB Rockland exhibit resistance to $H$. avenae $(43,45,48,52)$. Ouyen contains the single dominant Crel gene for resistance to $H$. avenae (41; http://wheatpedigree.net/sort/render Pedigree/15032). The source of WB Rockland resistance to PNW populations of $H$. avenae is unknown $(45,48)$. The pedigree of WB Rockland was described in Smiley et al. (48). It was previously reported that different cultivars may exhibit different hosting abilities for $H$. avenae and $H$. filipjevi $(15,22)$.

Two wheat cultivars that are resistant to moderately resistant to the population of $H$. filipjevi in Washington were identified during the course of this research. SY Steelhead is a recently released cultivar that could be utilized immediately on fields infested with H. filipjevi. Sönmez is produced on the Anatolian Plateau of Turkey, in regions where climatic conditions are very similar to the inland PNW. Sönmez was very competitive in grain yield with other PNW wheat cultivars in previous field trials in the PNW (48), but we did not examine the grain for quality characteristics that would be required for commercial production. One or both cultivars could be inserted into 3-year rotations composed of a susceptible or resistant winter wheat cultivar, a resistant spring cereal such as Sönmez or SY Steelhead, and a pulse crop or bare fallow. Barley may be an alternative for a resistant spring wheat in the 3-year rotation because spring barleys and oats were found to have greater resistance than spring wheat to $H$. filipjevi (16), although this would not be advised for soils infested with $H$. avenae. These 3year rotations would be expected to reduce the density of $H$. filipjevi during the 2-year interval between crops of a susceptible winter wheat cultivar $(5,28)$. Although eggs remain viable and are released over a period of years, the population declines by up to 70 to $80 \%$ annually by hatching and death of juveniles during periods of fallow or growth of nonhosts or resistant cultivars (3). The 3year rotation is nearly universally accepted as being of sufficient length between host crops to manage these Heterodera spp. at densities below a threshold for economic damage. 
The resistance or susceptibility of winter wheat cultivars to $H$. filipjevi in the PNW has not been defined. However, winter wheat cv. Madsen, developed and released in Washington (2), was identified as the most resistant cultivar tested in field and glasshouse screenings of wheat cultivars using $H$. filipjevi-infested soils from China (24). Resistance to $H$. filipjevi among spring wheat and winter wheat cultivars and lines were recently reported in Turkey $(8,18,30,58)$ and in China $(7,10)$. Multiple accessions originating in North American wheat breeding programs were found to be resistant to $H$. filipjevi populations in Turkey (8). Lastly, spring wheat cultivars have been screened in one of the fields highly infested with $H$. filipjevi near Colton, WA since 2012. Numerous cultivars and a mapping population derived from a cross between the spring wheat cvs. Louise and Ouyen have been screened at that location over the past 3 years. Reports from that work are likely to provide greater insight into potential cultivars that may be recommended for planting on $H$. filipjevi-infested fields.

Corn is a potential rotation crop because it is a poor host to both $H$. avenae and $H$. filipjevi $(4,21,34,40)$. Bajaj and Kanwar (4) suggested the possibility that corn could be planted as a trap crop to reduce the density of $\mathrm{CCN}$ in soil. After invading corn roots, the nematode either does not reproduce or it reproduces at a low rate. Nevertheless, an intolerant hypersensitive response to invasion may adversely affect rooting and yield (34). Corn and broadleaf nonhosts are frequently grown in rotations that include wheat in irrigated fields of the PNW, and some rain-fed corn is currently produced in areas of Whitman County that are infested with $H$. avenae.

An obligate diapause period is required before second-stage juveniles of $H$. avenae will emerge from brown cysts. This species generally requires that cysts be subjected to a cold-tempering period of about 2 months to establish optimal conditions for the release of the invasive juvenile stage during the spring $(28,35,60)$. For instance, in Russia, east of the Ural Mountains, $H$. avenae juveniles began to emerge from cysts in late April, and more than half the potential population was free living in soil when cereals were planted at the end of May (32). Newly produced cysts of $H$. avenae in India required a 1-month cold-tempering period at $4{ }^{\circ} \mathrm{C}$ to stimulate hatching (56). In eastern Oregon, juveniles of $H$. avenae are first detected in soil during late February, and the density increases rapidly during March (50). However, in warmer climates, as in Algeria, $H$. avenae hatching may begin during autumn (October) and extend through spring (April) (42). For H. filipjevi, juveniles begin to emerge from cysts during the autumn (October) and continue through spring (April) even in areas with cold winter climates, as in Turkey (39), Iran (12,40), and Norway (15). Sahin et al. (39) reported that juveniles of $H$. filipjevi exhibited two hatching peaks in Turkey, during October and February. It appears that $H$. filipjevi does not have a diapause requirement and can hatch anytime when hosts become available, as was suggested by Sahin et al. (39).

The discovery of $H$. filipjevi in Washington occurred in response to a routine application of molecular diagnostic tests recently developed in our laboratory (67). At least one commercial lab that serves the nematode diagnostic needs of growers throughout the western United States recently added these DNA-based tests for cyst nematodes to similar tests they were already using to detect and quantify fungal pathogens. We anticipate that the known distribution of $H$. filipjevi will be expanded as commercial laboratories begin using DNA-based technologies more widely. Surveys of fields already known to be infested by ' $H$. avenae' in the western United States need to be re-examined to determine if the species designation has been misidentified. This may be particularly true for eastern Oregon and eastern Washington, where $H$. filipjevi is now known to occur. Also, some fields now known to be infested by $H$. filipjevi are located only $5 \mathrm{~km}$ west of the Washington-Idaho border, and farming practices are nearly identical on both sides of that border. For existing and yet-to-be-identified infestations, a linkage of modern diagnostic methods and development of cultivars with resistance to $H$. avenae and $H$. filipjevi has the potential to improve yields of small grains in the PNW, as has been demonstrated in Norway (15).

\section{Acknowledgments}

We appreciate funding from the Idaho Wheat Commission, Oregon Wheat Commission, Washington Wheat Commission, Oregon Agricultural Experiment Station, and USDA-ARS Root Disease and Biological Control Unit (at Pullman, WA). Discounted nematode testing fees were provided by Western Laboratories (Parma, ID).

\section{Literature Cited}

1. Abidou, H., Valette, S., Gauthier, J. P., Rivoal, R., El-Ahmed, A., and Yahyaoui, A. 2005. Molecular polymorphism and morphometrics of species of the Heterodera avenae group in Syria and Turkey. J. Nematol. 37:146154.

2. Allan, R. E., Peterson, C. J., Rubenthaler, G. L., Line, R. F., and Roberts, D. E. 1989. Registration of Madsen wheat. Crop Sci. 29:1575.

3. Andersson, S. 1982. Population dynamics and control of Heterodera avenae A review with some original results. EPPO Bull. 12:463-475.

4. Bajaj, H. K., and Kanwar, R. S. 2005. Parasitism of maize by Heterodera avenae and $H$. filipjevi. Nematol. Mediterr. 33:203-207.

5. Baldwin, J. G., and Mundo-Ocampo, M. 1991. Heteroderinae, cyst- and non-cyst-forming nematodes. Pages 275-362 in: Manual of Agricultural Nematology. W. R. Nickle, ed. Marcel Dekker, New York.

6. Bekal, S., Gauthier, J. P., and Rivoal, R. 1997. Genetic diversity among a complex of cereal cyst nematodes inferred from RFLP analysis of the ribosomal internal transcribed spacer region. Genome 40:479-486.

7. Cui, L., Gao, X., Wang, X.-M., Jian, H., Tang, W.-H., Li, H.-L., and Li, H.J. 2012. Characterization of interaction between wheat roots with different resistance and Heterodera filipjevi. Acta Agron. Sinica 38:1009-1017.

8. Dababat, A. A., Ergınbaş-Orakci, G., Toktay, H., İmren, M., Akin, B. Braun, H.-J., Dreisigaker, S., Elekçığlu, İ. H., and Morgounov, A. 2014 Resistance of winter wheat to Heterodera filipjevi in Turkey. Turk. J. Agric. For. 38:180-186.

9. Esser, R. P. 1988. A simple method for examination of the vulva area of mature cysts of Heterodera spp. J. Nematol. 20:497-498.

10. Gao, X., Cui, L., Li, H.-L., Wang, X.-M., Tang, W.-H., Conner, R. L., Lin, X.-H., and Li, H.-J. 2012. Resistance of Triticum durum cultivars Waskana and Waskowa to cereal cyst nematode, Heterodera filipjevi and $H$. avenae. Acta Agron. Sinica 38:571-577.

11. Hafez, S. L., and Golden, A. M. 1984. First report of oat cyst nematode in eastern Washington. Plant Dis. 68:351.

12. Hajihasani, A., Tanha Maafi, Z., and Hajihasani, M. 2010. The life cycle of Heterodera filipjevi in winter wheat under microplot conditions in Iran. Nematol. Mediterr. 38:53-57.

13. Hall, T. A. 1999. BioEdit: A user-friendly biological sequence alignment editor and analysis program for Windows 95/98/NT. Nucleic Acid Symp. 41:95-98.

14. Handoo, Z. A. 2002. A key and compendium to species of the Heterodera avenae Group (Nematoda: Heteroderidae). J. Nematol. 34:250-262.

15. Holgado, R., Andersson, S., and Magnusson, C. 2006. Management of cereal cyst nematodes, Heterodera spp., in Norway. Comm. Appl. Biol. Sci. 71:639-645.

16. Holgado, R., Andersson, S., Rowe, J., Clark, I., and Magnusson, C. 2009. Management strategies for cereal cyst nematodes Heterodera spp. in Norway. Pages 154-159 in: Cereal Cyst Nematodes: Status, Research and Outlook. I. T. Riley, J. M. Nicol, and A. A. Dababat, eds. CIMMYT, Ankara, Turkey.

17. Holgado, R., Rowe, J. A., and Magnusson, C. 2004. Morphology of cysts and second stage juveniles of Heterodera filipjevi (Madzhidov, 1981) Stelter, 1984 from Norway. J. Nematol. Morph. Syst. 7:77-84.

18. İmren, M., Toktay, H., Bozbuğa, R., Erginbaş Orakçi, G., Dababat, A. and Elekçioglu, İ. H. 2013. Identification of genetic resistance to cereal cyst nematodes; Heterodera avenae (Wollenweber, 1924), Heterodera filipjevi (Madzhidov, 1981) Stelter and Heterodera latipons (Franklin, 1969) in some international bread wheat germplasms. Turk. J. Entomol. 37:277-282.

19. Ingham, R. E. 1994. Nematodes. Pages 459-490 in: Methods of Soil Analysis, Part 2. Microbiological and Biochemical Properties. R. W. Weaver, J. S Angle, and P. S. Bottomley, eds. Soil Science Society of America, Madison, WI.

20. Jensen, H. J., Eshtiaghi, H., Koepsell, P. A., and Goetze, N. 1975. The oat cyst nematode, Heterodera avenae, occurs in oats in Oregon. Plant Dis. Rep. 59:1-3.

21. Johnson, P. W., and Fushtey, S. G. 1966. The biology of the oat cyst nematode Heterodera avenae in Canada. II. Nematode development and related anatomical changes in roots of oats and corn. Nematologica 12:630-636.

22. Kanwar, R. S., Bajaj, J. K., and Vats, R. 2004. Development of Heterodera filipjevi on wheat varieties resistant to Heterodera avenae. Indian J. Nematol. 34:205-206.

23. Krusberg, L. R., Sardanelli, S., Meyer, S. L. F., and Crowley, P. 1994. A method for recovery and counting of nematode cysts. J. Nematol. 26(4S):599. 
24. Li, H., Cui, L., Li, H., Wang, X., Murray, T. D., Conner, R. L., Wang, L., Gao, X., Sun, Y., Sun, S., and Tang, W. 2012. Effective resources in wheat and wheat-Thinopyrum derivatives for resistance to Heterodera filipjevi in China. Crop Sci. 52:1209-1217.

25. Lücke, E. 1976. Pathotypen-Untersuchungen mit Heterodera avenae-populationen (1966-1975). Z. Pflanzenkr. Pflanzensc. 83:647-656.

26. Madani, M., Vovlas, N., Castillo, P., Subbotin, S. A., and Moens, M. 2004. Molecular characterization of cyst nematode species (Heterodera spp.) from the Mediterranean Basin using RFLPs and sequences of ITS-rDNA. J. Phytopathol. 152:229-234

27. Martin, P. J. 1994. Triticum aestivum ssp. vulgare (bread wheat) cv. Ouyen. Aust. J. Exp. Agric. 34:863.

28. McDonald, A. H., and Nicol, J. M. 2005. Nematode parasites of cereals. Pages 131-191 in: Plant Parasitic Nematodes in Subtropical and Tropical Agriculture. M. Luc, R. A. Sikora, and J. Bridge, eds. CAB International, Wallingford, UK

29. Mokabli, A., Valette, S., Gauthier, J.-P., and Rivoal, R. 2002. Variation in virulence of cereal cyst nematode populations from North Africa and Asia. Nematology 4:521-525.

30. Nicol, J. M., Bolat, N., Yildirim, A. F., Yorgancilar, A., Kilinç, A. T., Eleckçioğlu, İ. H., Şahin, E., Erginbaş-Orakçi, G., and Braun, H. J. 2009. Identification of genetic resistance to cereal cyst nematode (Heterodera filipjevi) for international bread wheat improvement. Pages 160-165 in: Cereal Cyst Nematodes: Status, Research and Outlook. I. T. Riley, J. M. Nicol, and A. A. Dababat, eds. CIMMYT, Ankara, Turkey.

31. Oliveira, R. D. L., Santin, Â. M., Seni, D. J., Dietrich, A., Salazar, L. A., Subbotin, S. A., Mundo-Ocampo, M., Goldenberg, R., and Barreto, R. W. 2013. Ditylenchus gallaeformans sp. n. (Tylenchida: Anguinidae) - A neotropical nematode with biocontrol potential against weedy Melastomataceae. Nematology 15:179-196.

32. Popova, M. B. 1971. Biological characteristics of Heterodera avenae in Bashkir ASSR. Byulleten' Vsesoyuznogo Instituta Gel'mintologii im. K. I. Skryabina 1071:47-52.

33. Riley, I. T., Nicol, J. M., and Dababat, A. A. 2009. Cereal Cyst Nematode: Status, Research and Outlook. CIMMYT, Ankara, Turkey.

34. Rivoal, R. 1973. Accidents végétatifs et parasitaires au début de la croissance du mäis dans l'ouest de la France. La maladie vermiculaire du mäis causée par le nématode à kyste des céréals, Heterodera avenae. Sci. Agron. Rennes 1973:223-224.

35. Rivoal, R., and Cook, R. 1993. Nematode pests of cereals. Pages 259-303 in: Plant Parasitic Nematodes in Temperate Agriculture. K. Evans, D. L. Trudgill, and J. M. Webster, eds. CAB International, Wallingford, UK.

36. Rivoal, R., Valette, S., Bekal, S., Gauthier, J.-P., and Yahyaoui, A. 2003. Genetic and phenotypic diversity in the graminaceous cyst nematode complex, inferred from PCR-RFLP of ribosomal DNA and morphometric analysis. Eur. J. Plant Pathol. 109:227-241.

37. Rumpenhorst, H. J., Elekçığlu, İ. H., Sturhan, D., Öztürk, G., and Enneli, S. 1996. The cereal cyst nematode Heterodera filipjevi (Madzhidov) in Turkey. Nematol. Mediterr. 24:135-138.

38. Sağlam, H. D., Çobanoğlu, S., Wesemael, W., Nicol, J. M., Viaene, N., and Dababat, A. A. 2009. Preliminary investigation of resistance in winter wheat to Heterodera filipjevi under controlled conditions. Pages 172-176 in: Cereal Cyst Nematodes: Status, Research and Outlook. I. T. Riley, J. M. Nicol, and A. A. Dababat, eds. CIMMYT, Ankara, Turkey.

39. Sahin, E., Nicol, J. M., Elekcioglu, I. H., and Rivoal, R. 2010. Hatching of Heterodera filipjevi in controlled and natural temperature conditions in Turkey. Nematology 12:193-200.

40. Seifi, S., Karegar, A., and Banihashemi, Z. 2013. The life cycle of the cereal cyst nematode, Heterodera filipjevi, and effect of plant hosts on its population. World Appl. Programm. 3:164-168.

41. Slootmaker, L. A. J., Lange, W., Jochemsen, G., and Schepers, J. 1974. Monosomic analysis in bread wheat of resistance to cereal root eelworm. Euphytica 23:497-503.

42. Smaha, D., Hamroun, O., and Mokabli, A. 2009. Soil temperature and hatching of Heterodera avenae in Algeria. Pages 130-133 in: Cereal Cyst Nematodes: Status, Research and Outlook. I. T. Riley, J. M. Nicol, and A. A. Dababat, eds. CIMMYT, Ankara, Turkey.

43. Smiley, R. W. 2009. Occurrence, distribution and control of Heterodera avenae and $H$. filipjevi in the western USA. Pages 35-40 in: Cereal Cyst Nematodes: Status, Research, and Outlook. I. T. Riley, J. M. Nicol, and A. A. Dababat, eds. CIMMYT, Ankara, Turkey.

44. Smiley, R. W. 2012. A fluidizing column for extracting cysts of Heterodera avenae from soil. Plant Dis. 96:820-826.

45. Smiley, R. W. 2014. Resistance of wheat to a Pacific Northwest population of Heterodera avenae, 2013. Plant Dis. Manag. Rep. 9:CF039.
46. Smiley, R. W., Ingham, R. E., Uddin, W., and Cook, G. H. 1994. Crop sequences for managing cereal cyst nematode and fungal pathogens of winter wheat. Plant Dis. 78:1142-1149.

47. Smiley, R. W., and Marshall, J. M. 2014. Spring wheat resistance and tolerance to cereal cyst nematode. Plant Dis. Manag. Rep. 8:N008.

48. Smiley, R. W., Marshall, J. M., Gourlie, J. A., Paulitz, T. C., Kandel, S. L., Pumphrey, M. O., Garland-Campbell, K., Yan, G. P., Anderson, M. D., Flowers, M. D., and Jackson, C. A. 2013. Spring wheat tolerance and resistance to Heterodera avenae in the Pacific Northwest. Plant Dis. 97:590-600.

49. Smiley, R. W., and Nicol, J. M. 2009. Nematodes which challenge global wheat production. Pages 171-187 in: Wheat Science and Trade. B. F Carver, ed. Wiley-Blackwell Publishers, Ames, IA.

50. Smiley, R. W., Whittaker, R. G., Gourlie, J. A., Easley, S. A., and Ingham, R. E. 2005. Plant-parasitic nematodes associated with reduced wheat yield in Oregon: Heterodera avenae. J. Nematol. 37:297-307.

51. Smiley, R. W., Yan, G. P., and Handoo, Z. A. 2008. First record of the cyst nematode Heterodera filipjevi on wheat in Oregon. Plant Dis. 92:1136.

52. Smiley, R. W., Yan, G. P., and Pinkerton, J. N. 2011. Resistance of wheat, barley and oat to Heterodera avenae in the Pacific Northwest USA. Nematology 13:539-552.

53. Subbotin, S. A., Sturhan, D., Rumpenhorst, H. J., and Moens, M. 2003. Molecular and morphological characterisation of the Heterodera avenae species complex (Tylenchida: Heteroderidae). Nematology 5:515-538.

54. Subbotin, S. A., Waeyenberge, L., and Moens, M. 2000. Identification of cyst forming nematodes of the genus Heterodera (Nematoda: Heteroderidae) based on the ribosomal DNA-RFLPs. Nematology 2:153-164.

55. Subbotin, S. A., Waeyenberge, L., Molokanova, I. A., and Moens, M. 1999. Identification of Heterodera avenae group species by morphometrics and rDNA-RFLPs. Nematology 1:195-207.

56. Swarup, G., and Gill, J. S. 1972. Factors influencing emergence of larvae from cysts of Heterodera avenae Wollenw. Ind. J. Exp. Biol. 10:219-223.

57. Tanha Maafi, Z., Subbotin, S. A., and Moens, M. 2003. Molecular identification of cyst-forming nematodes (Heteroderidae) from Iran and a phylogeny based on ITS-rDNA sequences. Nematology 5:99-111.

58. Toktay, H., Yavuzaslanoğlu, E., İmren, M., Nicol, J., Elekçioglu, İ. H., and Dababat, A. 2012. Screening for resistance to Heterodera filipjevi (Madzhidov, 1981) Stelter (Tylenchida: Heteroderidae) and Pratylenchus thornei (Sher \& Allen) (Tylenchida: Pratylenchidae) in sister lines of spring wheat. Turk. J. Entomol. 36:455-461.

59. Toumi, F., Waeyenberge, L., Viaene, N., Dababat, A., Nicol, J. M., Ogbonnaya, F., and Moens, M. 2013. Development of two species-specific primer sets to detect the cereal cyst nematodes Heterodera avenae and Heterodera filipjevi. Eur. J. Plant Pathol. 136:613-624.

60. Turner, S. J., and Subbotin, S. A. 2013. Cyst nematodes. Pages 109-143 in: Plant Nematology, 2nd ed. R. N. Perry and M. Moens, eds. CAB International., Wallingford, UK.

61. Washington Wheat Commission. 1999. Washington wheat facts. On-line, accessed on 16 July 2014. http://www.bluefish.org/wheatfax.htm

62. Whitehead, A. G., and Hemming, J. R. 1965. A comparison of some quantitative methods of extracting small vermiform nematodes from soil. Ann. Appl. Biol. 55:25-38

63. Wouts, W. M., and Baldwin, J. G. 1998. Taxonomy and identification. Pages 83-122 in: The Cyst Nematodes. S. B. Sharma, ed. Klumer Acad. Publ. London, UK

64. Yan, G. P., and Smiley, R. W. 2009. Discovery of Heterodera filipjevi on wheat in the USA. Pages 94-99 in: Cereal Cyst Nematodes: Status, Research, and Outlook. I. T. Riley, J. M. Nicol, and A. A. Dababat, eds CIMMYT, Ankara, Turkey.

65. Yan, G. P., and Smiley, R. W. 2010. Distinguishing Heterodera filipjevi and $H$. avenae using polymerase chain reaction-restriction fragment length polymorphism and cyst morphology. Phytopathology 100:216-224.

66. Yan, G. P., Smiley, R. W., and Okubara, P. A. 2012. Detection and quantification of Pratylenchus thornei in DNA extracted from soil using real-time PCR. Phytopathology 102:14-22.

67. Yan, G. P., Smiley, R. W., Okubara, P. A., and Skantar, A. 2013. Speciesspecific PCR assays for differentiating Heterodera filipjevi and $H$. avenae. Plant Dis. 97:1611-1619.

68. Yan, G. P., Smiley, R. W., Okubara, P. A., Skantar, A., Easley, S. A., Sheedy, J. G., and Thompson, A. L. 2008. Detection and discrimination of Pratylenchus neglectus and $P$. thornei in DNA extracts from soil. Plant Dis. 93:1480-1487.

69. Yan, G. P., Smiley, R. W., Okubara, P. A., Skantar, A. M., and Reardon, C. L. 2013. Developing a real-time PCR assay for detection and quantification of Pratylenchus neglectus in soil. Plant Dis. 97:757-764. 